\title{
Gorgonopsian therapsids (Nochnitsa gen. nov. and Viatkogorgon) from the Permian Kotelnich locality of Russia
}

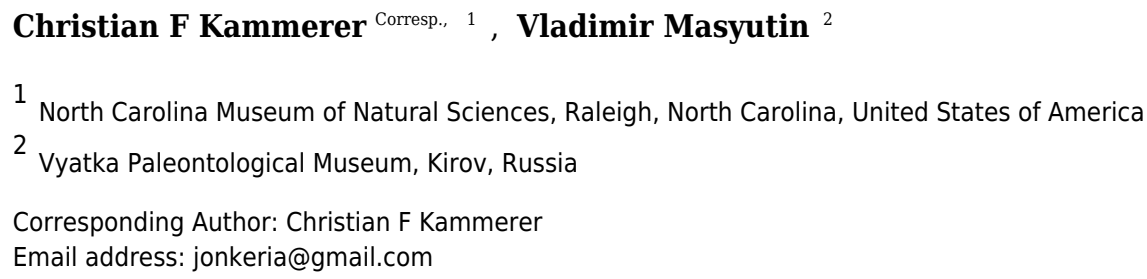

The early evolution of gorgonopsians is poorly understood. New material from the Kotelnich locality in Russia expands our knowledge of middle/earliest late Permian gorgonopsians from Laurasia. Two gorgonopsian taxa are recognized from Kotelnich: Viatkogorgon ivakhnenkoi Tatarinov, 1999 and Nochnitsa geminidens gen. et sp. nov. Nochnitsa can be distinguished from all known gorgonopsians by its unique upper postcanine tooth row, composed of pairs of teeth (a small anterior and larger posterior) separated by diastemata. Both Viatkogorgon and Nochnitsa are relatively small gorgonopsians, comparable in size to the South African middle Permian taxon Eriphostoma. Inclusion of Viatkogorgon and Nochnitsa in a phylogenetic analysis of gorgonopsians recovers them in basal positions, with Nochnitsa representing the earliestdiverging gorgonopsian genus. All other sampled gorgonopsians fall into two major subclades: one made up entirely of Russian taxa (Inostrancevia, Pravoslavlevia, Sauroctonus, and Suchogorgon) and the other containing only African gorgonopsians. The high degree of endemism indicated in this analysis for gorgonopsians is remarkable, especially given the extensive intercontinental dispersal inferred for coeval therapsid groups. 
1 Gorgonopsian therapsids (Nochnitsa gen. nov. and Viatkogorgon) from the Permian

2 Kotelnich locality of Russia

3

4 Christian F. Kammerer ${ }^{1}$ and Vladimir V. Masyutin ${ }^{2}$

5

$6{ }^{1}$ North Carolina Museum of Natural Sciences, 11 W. Jones Street, Raleigh, North Carolina, USA

$7 \quad$ 2Vyatka Paleontological Museum, Spasskaya ulitsa 22, Kirov, Russia 610000

8

9 Correspondence to: C. F. Kammerer (christian.kammerer@naturalsciences.org)

11 Abstract. The early evolution of gorgonopsians is poorly understood. New material from the

12 Kotelnich locality in Russia expands our knowledge of middle/earliest late Permian

13 gorgonopsians from Laurasia. Two gorgonopsian taxa are recognized from Kotelnich:

14 Viatkogorgon ivakhnenkoi Tatarinov, 1999 and Nochnitsa geminidens gen. et sp. nov.

15 Nochnitsa can be distinguished from all known gorgonopsians by its unique upper postcanine

16 tooth row, composed of pairs of teeth (a small anterior and larger posterior) separated by

17 diastemata. Both Viatkogorgon and Nochnitsa are relatively small gorgonopsians, comparable

18 in size to the South African middle Permian taxon Eriphostoma. Inclusion of Viatkogorgon and

19 Nochnitsa in a phylogenetic analysis of gorgonopsians recovers them in basal positions, with

20 Nochnitsa representing the earliest-diverging gorgonopsian genus. All other sampled

21 gorgonopsians fall into two major subclades: one made up entirely of Russian taxa

22 (Inostrancevia, Pravoslavlevia, Sauroctonus, and Suchogorgon) and the other containing only

23 African taxa. The high degree of endemism indicated in this analysis for gorgonopsians is

24 remarkable, especially given the extensive intercontinental dispersal inferred for coeval

25 therapsid groups. 


\section{INTRODUCTION}

28 The therapsid subclade Gorgonopsia was an abundant but morphologically conservative group

29 of saber-toothed carnivores that included the apex predators of the late Permian (Sigogneau-

30 Russell, 1989; Kammerer, 2015, 2016). Despite their omnipresence in the late Permian

31 therapsid faunas of southern Africa (Sigogneau, 1970; Smith et al., 2012), gorgonopsians are

32 poorly represented in the global fossil record. No gorgonopsian fossils have thus far been found

33 in the middle-to-late Permian deposits of western Europe, South America, or southeast Asia

34 (Benton \& Walker, 1985; Sues \& Munk, 1996; Bercovici et al., 2012; Dias-da-Silva, 2012; Boos

35 et al., 2015). Young (1979) described a supposed gorgonopsian taxon (Wangwusaurus

36 tayuensis) from the Jiyuan Formation of China, but the type material of this taxon consists of a

37 chimaerical assortment of temnospondyl and pareiasaur teeth (Liu et al., 2014). Although a

38 serrated canine from the Jiyuan Formation could represent an actual gorgonopsian (Liu et al.,

39 2014), this identification cannot be confirmed by this element alone (it could just as easily

40 represent a therocephalian, and indeed Liu et al. [2014] noted its similarity to teeth of the early

41 therocephalian Lycosuchus). As such, the presence of gorgonopsians in the Chinese record

42 remains dubious. Ray \& Bandyopadhyay (2003) referred several skull fragments (premaxillary

43 and vomerine elements and isolated dentary symphyses) from the Kundaram Formation of India

44 to Gorgonopsia. These specimens are likely to represent true gorgonopsians: the steep, robust

45 morphology of these symphyses, with the incisor and canine tooth row elevated high above the

46 postcanine row, is typical of the group. However, although this morphology is typical for

47 gorgonopsians it is not exclusive to them; again, some therocephalian taxa exhibit a very similar

48 morphology (Durand, 1991). Of the extra-African regions yielding Permian tetrapod fossils, only

49 Russia has thus far produced definitive gorgonopsian remains.

50 The history of gorgonopsian discoveries in Russia dates back to the 1890s, beginning

51 with the massive excavations of V. P. Amalitzky at the Sokolki locality along the North Dvina

52 River (Ochev \& Surkov, 2000). Amalitzky collected extensive remains of late Permian 
53 gorgonopsians, which were initially, briefly described as a new species in a posthumous

54 publication (Amalitzky, 1922). This first Russian gorgonopsian, Inostrancevia alexandri, remains

55 the best-known taxon from the Northern Hemisphere, and has become one of the most famous

56 Permian animals because of its gigantic size (among gorgonopsians, rivaled only by Rubidgea

57 atrox from southern Africa). The genus name of this animal was spelled "Inostranzevia" in its

58 initial description (Amalitzky, 1922), but the spelling Inostrancevia has since come into universal

59 usage and must be maintained (under Art. 33.3.1 of the International Code of Zoological

60 Nomenclature [ICZN, 1999]). Pravoslavlev (1927) subsequently produced a monographic

61 account of the North Dvina gorgonopsians, recognizing three additional species of Inostrancevia

62 (I. latifrons, I. parva, and I. proclivis) and the new genus Amalitzkia (containing two species, $A$.

63 wladimiri and $A$. annae).

64 Hartmann-Weinberg (1938) described another new species of Russian gorgonopsian,

65 albeit placing it in the South African genus Arctognathus: A. progressus from the Tetyushkii

66 District of Tatarstan. Whereas South African gorgonopsian discoveries continued at an alarming

67 pace during this time (Wyllie, 2003), this was mostly a fallow period for Russian gorgonopsian

68 research, with few new specimens being collected. Vjuschkov (1953) revised the North Dvina

69 gorgonopsians, recognizing a new genus (Pravoslavlevia) for the small species Inostrancevia

70 parva (which Efremov [1940] had previously considered to represent a juvenile of one of the

71 larger Inostrancevia species). Bystrov (1955) revised A. progressus, placing it in a new genus,

72 Sauroctonus. Tatarinov (1974) revised all theriodonts from the Soviet Union in a comprehensive

73 monograph on the group, and named a new species of Inostrancevia (I. uralensis) based on an

74 isolated braincase from the Blumental-3 locality of the Orenburg Region.

Additional Russian gorgonopsian taxa were not recognized until the turn of the century,

76 with the description of the small gorgonopsians Viatkogorgon ivakhnenkoi from the Kotelnich

77 locality of the Kirov Region (Tatarinov, 1999a) and Suchogorgon golubevi from the Ust'e

78 Strel'ny locality of the Vologda Region (Tatarinov, 2000a). Most recently, another isolated 
braincase (from the Klimovo-1 locality of the Vologda Region) was made the holotype of Leogorgon klimovensis, purportedly the first Russian rubidgeine gorgonopsian (Ivakhnenko,

81 2003; although see Kammerer [2016] for doubts on this identification).

Since the description of Viatkogorgon, no other gorgonopsians have been described from the Kotelnich locality, despite an explosion in the therocephalian diversity reported from this area (Tatarinov, 1999b, 2000b; Ivakhnenko, 2011). Here, we provide evidence for a second taxon of Kotelnich gorgonopsian based on a complete skull and partial skeleton in the collections of the Vyatka Paleontological Museum, redescribe the cranium of Viatkogorgon for comparison, and place these taxa in a phylogenetic context.

\section{Nomenclatural acts}

90 The electronic version of this article in portable document format (PDF) will represent a

91 published work according to the International Commission on Zoological Nomenclature (ICZN),

92 and hence the new names contained in the electronic version are effectively published under

93 that Code from the electronic edition alone. This published work and the nomenclatural acts it

94 contains have been registered in ZooBank, the online registration system for the ICZN. The

95 ZooBank LSIDs (Life Science Identifiers) can be resolved and the associated information

96 viewed through any standard web browser by appending the LSID to the prefix

97 http://zoobank.org/. The LSID for this publication is: urn:Isid:zoobank.org:pub:397E7247-DB64-

98 4B99-B24E-5A2E2DA87B48. The online version of this work is archived and available from the

99 following digital repositories: PeerJ, PubMed Central, and CLOCKSS.

\section{Institutional abbreviations}

102 BP, Evolutionary Studies Institute, University of the Witwatersrand, Johannesburg, South Africa;

103 GPIT, Paläontologische Sammlung, Eberhard-Karls-Universität Tübingen, Germany; KPM,

104 Vyatka Paleontological Museum, Kirov, Russia; NHMUK, the Natural History Museum, London, 
105 UK; PIN, Paleontological Institute of the Russian Academy of Sciences, Moscow, Russia; RC,

106 Rubidge Collection, Wellwood, Graaff-Reinet, South Africa; SAM, Iziko: The South African

107 Museum, Cape Town, South Africa; UMZC, University Museum of Zoology, Cambridge, UK.

108

109 GEOLOGICAL CONTEXT

110 The Kotelnich locality consists of a series of Permian red bed exposures along the banks of the

111 Vyatka River in the Kotel'nichskii District of Kirov Region. This locality is one of the most

112 productive Permian tetrapod sites in Russia, and is especially well known for its pareiasaur

113 remains (Efremov \& Vjuschkov, 1955). Although the paleontological importance of the Kotelnich

114 beds has long been recognized (Hartmann-Weinberg, 1937), the geology and stratigraphy of

115 this locality was poorly understood until work by Coffa $(1997 a, 1997 b, 1998,1999)$ as part of his

$116 \mathrm{PhD}$ research. He recognized five lithological members making up the Kotelnich red beds: (in

117 descending order) the Sokol'ya-Gora Member (brown fine-grained fluvial sandstone), Chizhi

118 Member (fine-grained gray sandstone; originally spelled "Chizhy" but emended by Benton et al.

119 [2012]), Shestakovy Member (brown-gray mudstone), Boroviki Member (orange fine-grained

120 aeolian sandstone), and Vanyushonki Member (red-brown calcareous clay and mudstone).

121 More recent studies have generally upheld Coffa's stratigraphic scheme. Although there has

122 been some disagreement in precise interpretation of the succession (Golubev, 2000;

123 Tverdokhlebov, 2009), the most recent comprehensive stratigraphic and sedimentological

124 overview of the Kotelnich locality (Benton et al., 2012) followed the five-member scheme and

125 nomenclature of Coffa (1999). Benton et al. (2012) also provided the most up-to-date geological

126 maps and stratigraphic sections for Kotelnich, illustrating the positions in section that have

127 yielded vertebrate fossils (Benton et al. 2012:fig.7).

128 The Vanyushonki Member is the oldest rock unit in the Kotelnich succession and the

129 source of most of the fossil tetrapods from this locality. Skeletal remains are abundant in this

130 member and often consist of complete, articulated skeletons. The Vanyushonki Member is 
131 composed mainly of pale or moderate brown mudstones (clays/silts with small quantities of fine-

132 grained sand). This horizon also contains an inclusion of gray and bluish-gray mudstone and

133 two horizons of dark red mudstone at the base of the exposure. Benton et al. (2012) argued that

134 mudstones of the Vanyushonki Member were probably deposited from suspension in standing

135 water bodies on floodplains or in shallow ephemeral lakes, but noted that in the absence of

136 primary sedimentary structure, the exact depositional environment could not be determined.

137 This member has yielded the most diverse vertebrate assemblage at Kotelnich. In addition to

138 the extremely abundant pareiasaurs (Deltavjatia rossica), the Vanyushonki Member has also

139 produced 'nycteroleter' parareptiles (Emeroleter laevis) and various therapsid taxa (including the

140 basal anomodont Suminia getmanovi, the gorgonopsian Viatkogorgon ivakhnenkoi, and the

141 therocephalians Chlynovia serridentata, Karenites ornamentatus, Perplexisaurus foveatus,

142 Scalopodon tenuisfrons, Scalopodontes kotelnichi, and Viatkosuchus sumini) (Ivakhnenko,

143 2008; Tsuji, 2013).

144 Benton et al. (2012) considered the Kotelnich faunal complex to be latest Guadalupian in

145 age, and equivalent to the Pristerognathus Assemblage Zone (AZ) of the South African Karoo

146 Basin. More recent research on the South African assemblage zones, however, indicates that

147 the boundary between the Tapinocephalus and Pristerognathus AZs is latest Guadalupian

148 (260.26 Ma) and the bulk of the Pristerognathus AZ may actually be early Lopingian (Day et al.,

149 2015). Kurkin (2011) suggested that the Kotelnich assemblage was better correlated with the

150 South African Tropidostoma AZ, based on the shared presence of toothed oudenodontid

151 dicynodonts (Australobarbarus in Russia and Tropidostoma in South Africa). However,

152 Australobarbarus fossils are found at a different site (Port Kotelnich) than most of the known

153 Kotelnich vertebrates. As discussed by Benton et al. (2012), the Port Kotelnich outcrop is not

154 easily correlated with the other Kotelnich sections. They suggested, however, that the Port

155 Kotelnich strata are substantially higher in section (probably representing the Shestakovy

156 Member) than the Vanyushonki Member beds that produce the other articulated tetrapod 
157 specimens. Based on our experience at Port Kotelnich, we agree that the Australobarbarus-

158 bearing beds are most likely in the Shestakovy Member, and as such are not necessarily

159 indicative of the age of the main Vanyushonki Member fauna.

160 The specimen KPM 310 (holotype of the new taxon Nochnitsa geminidens described

161 below) was collected by A. Khlyupin in 1994, in a red mudstone of the Vanyushonki Member

162 along the north bank of the Vyatka River. It was collected at the Sokol'ya Gora-Chizhi site, 43

163 meters upstream from the third ravine of the Sokol'ya Gora lens. Following collection, the

164 specimen was mechanically prepared at the Vyatka Paleontological Museum by O. Masyutina.

165

166 SYSTEMATIC PALEONTOLOGY

167 Synapsida Osborn, 1903

168 Therapsida Broom, 1905

169 Gorgonopsia Seeley, 1894

170

171 Nochnitsa gen. nov.

172

173

LSID: urn:Isid:zoobank.org:act:8FF18791-BAAD-45AC-946A-722A3BF83139

174 Type species: Nochnitsa geminidens sp. nov. Etymology: Named after a nocturnal spirit in Slavic legend (also the namesake for Myotis bats in modern Russian), often portrayed as a horrific female apparition that attacks

177 sleeping humans. Name intended as a regionally-appropriate counterpart to the usual

178 gorgonopsian generic stem 'gorgon', referring to monstrous hags from Greek myth. Feminine.

179 Diagnosis: As for type and only species.

180

181 Nochnitsa geminidens sp. nov.

182 (Figures 1-6) 
Holotype: KPM 310, a nearly complete skull and lower jaws with articulated vertebrae, ribs, and partial right forelimb from the Kotelnich locality, Kotel'nichskii District, Kirov Region,

187 Russia.

188 Etymology: From the Latin geminus ('twin') and dens ('tooth'), referring to the autapomorphic 'twinned' sets of postcanines in this species. A noun in apposition.

Diagnosis: Distinguished from all other known gorgonopsians by the autapomorphic 'twinning' of its upper postcanines, with the postcanine tooth row consisting of pairs of teeth separated by short diastemata. Further distinguished from the co-occurring gorgonopsian Viatkogorgon ivakhnenkoi by the higher upper postcanine tooth count (six, versus four in Viatkogorgon), upper incisor tooth row nearly in-line with postcanine tooth row (instead of elevated above it), absence of a maxillary flange around the canines, straight (rather than recurved) postcanine crowns, weak mandibular symphysis without a steep, distinct 'chin', proportionally longer snout, smaller orbit, broader intertemporal region, shorter temporal fenestra, dorsoventrally narrower subtemporal arch, absence of a squamosal flange at the posteroventral corner of the temporal fenestra, dorsoventrally narrower dentary ramus, and relatively posterior position of the reflected lamina (mostly beneath the temporal fenestra rather than the orbit). Distinguished from the South African middle Permian gorgonopsian Eriphostoma microdon by the absence of a labial emargination on the maxilla, longer snout, narrower postorbital bar, and higher upper postcanine tooth count (three in Eriphostoma). consists of an almost-complete skull, anterior axial column, and right forelimb (Figs. 1, 2). The skull is relatively small for a gorgonopsian (82 $\mathrm{mm}$ dorsal length). The right side of the skull is obscured by the radius, ulna, and autopodial elements (Fig. 2), but the left side is fully exposed (Fig. 1). The skull is generally well preserved (Figs. 3, 4C), although some sutural details are 
obscure and the snout has suffered some surface cracking (Fig. 3). Additionally, the left side of

210 the skull is largely undistorted, although the right side has suffered from some lateral

211 compression (Figs. 5, 6). A large crack extends from the anterior edge of the left orbit across the

212 interorbital region to the right temporal fenestra and has been filled with plaster (Fig. 5);

213 additional small cracks have been filled with silicone rubber (Figs. 3, 6).

214 The premaxilla is damaged anteriorly, with the internarial bar broken off, and the palatal

215 surface is completely obscured by the occluded mandible (Fig. 4D). The left premaxilla is largely

216 worn off, although the roots of the incisors remain in place (Fig. 2). The right facial portion of the

217 premaxilla has some surficial cracking but is otherwise intact. The premaxilla has a very short

218 contribution to the side of the snout ( $6 \mathrm{~mm}$ out of a $46 \mathrm{~mm}$ long snout), being mostly overlapped

219 by the maxilla laterally (Fig. 4D). The premaxillary-maxillary suture is immediately ventral to the

220 septomaxilla, and terminates between 12 and 13 at the alveolar margin of the snout. Five upper

221 incisors are present, as in most gorgonopsians. The incisors are mesiodistally narrow and

222 needle-like anteriorly but become progressively apicobasally shorter and mesiodistally broader

223 posteriorly. The upper incisors are weakly recurved and finely serrated on their distal margins

224 (no mesial serrations are evident, although as the mesial margin of these teeth is slightly angled

225 inwards they may be obscured).

226 The septomaxilla has a broad plate making up the floor of the external naris ventrally, a

227 constricted middle section separating the external naris from the large maxillo-septomaxillary

228 foramen, and a narrow, attenuate facial process extending between the maxilla and nasal (Fig.

229 4D). Because of damage to the premaxilla at the snout tip, more of the septomaxilla is exposed

230 laterally than would have been present naturally, giving this element a more primitive,

231 "pelycosaurian" appearance than would have been present in the intact skull (compare Fig. 4D

232 with the undamaged septomaxilla of Viatkogorgon in Fig. 4B). Because of damage to the

233 anterodorsal margin of the maxilla, the maxillary-septomaxillary foramen is also larger than

234 would normally have been the case. 

gorgonopsians, even similarly long-snouted forms such as Cyonosaurus (Olson, 1937;

237 Sigogneau-Russell,1989). The lateral surface of the maxilla bears distinct dermal sculpturing in 238 the form of radiating ridges extending outwards from the region around the canine root (Fig. 3).

239 The lateral surface of the maxilla is also densely foraminated, particularly above the tooth row.

240 The posterior process of the maxilla is a narrow, attenuate structure underlying the jugal, which

241 terminates below the midpoint of the orbit. The alveolar margin of the maxilla is weakly convex,

242 with a marked embayment anteriorly at the diastema between the incisors and canine. The

243 canine is relatively small and narrow (18 $\mathrm{mm}$ apicobasal length, $6 \mathrm{~mm}$ width at base) for a

244 gorgonopsian. The canine is clearly serrated posteriorly, but there is no evidence of anterior

245 serrations (although as for the incisors, because of the angulation of the canines and some

246 matrix covering, the absence of anterior serrations should not be taken as certain). Both

247 functional canines are in the anterior alveoli in this specimen, with replacement canines erupting

248 in the posterior alveoli at the time of death (Fig. 4D, 5). The right replacement canine was more

249 fully erupted-although it is badly damaged, its tip would have reached near mid-height of the

250 right canine (Fig. 4D). The left replacement canine is present only as a newly-erupted tip,

251 shorter than any of the postcanines (Fig. 4D).

252 Six right and five left upper postcanines are present. The morphology of the right upper

253 postcanine tooth row is unique among therapsids, consisting of three pairs of postcanines

254 separated by short ( 2 mm) diastemata (Fig. 5). Furthermore, in each of these pairs the anterior

255 tooth is smaller than its posterior counterpart (lengths of PC1: $5 \mathrm{~mm}$ vs. PC2: $7 \mathrm{~mm}$; PC3: $5 \mathrm{~mm}$

256 vs. PC4: 8 mm; PC5: 5 mm, PC6 damaged so length uncertain, but anteroposteriorly broader

257 than PC5). Other than in size, all postcanines are morphologically similar, being elongate,

258 weakly posteriorly-canted but not recurved, and bearing fine posterior serrations (and in these

259 teeth, the anterior face is well-exposed enough to confidently state that anterior serrations are

260 absent). Diastemata breaking up sections of the postcanine tooth row are otherwise unknown in 
261 gorgonopsians, but this does not seem to be an artifact of replacement in this specimen, as the

262 gaps between tooth pairs show no signs of empty alveoli or developing crowns. On the left side,

263 the posterior two postcanines (PC5 and 6) are paired in exactly the same way as the teeth on

264 the right side (PC5: $3.5 \mathrm{~mm}$ vs. PC6: $6 \mathrm{~mm}$ length). The anterior three postcanines do not form

265 similarly distinct pairs, but this seems to be the result of PC1 missing as part of the replacement

266 history of the dentition. If this is the case, then the first preserved left postcanine represents

267 PC2. This tooth is shorter than any other upper postcanine and appears to be newly-erupted-if

268 the pairs erupt in tandem a shorter PC1 may not yet have erupted. Under this interpretation,

269 PC3 and 4 can also be interpreted as a pair: although their bases are not in direct contact as in

270 the other pairs, PC3 (4 mm length) is shorter than PC4 (6 mm length), comparable to the right

271 postcanines.

272 The nasal is an elongate bone making up the dorsal roof of the snout (Fig. 5A). It bears

273 low anteroposterior ridges but is overall weakly ornamented compared to the maxilla. Its

274 posterior suture with the frontal is situated anterior to the orbits.

275 The prefrontal is a dorsoventrally low but anteroposteriorly extensive bone at the

276 anterodorsal margin of the orbit (Figs. 4D,6A). It has a sharp margin at the edge of the orbit but

277 not an expanded or rugose circumorbital rim. Below the prefrontal, the lacrimal is a small,

278 rhomboidal bone. Both of these elements bear irregular, ridged dermal sculpturing. The lacrimal

279 foramen does not exit laterally on the lacrimal, it is restricted to the internal orbital surface.

280 The jugal has a broad facial portion below the lacrimal (Fig. 4D), but this facial portion is

281 relatively small compared to other gorgonopsians (see, e.g., Viatkogorgon; Fig. 4B). Posterior to

282 this the jugal is a narrow, rod-like bone forming the zygoma. It is overlapped by the postorbital

283 under the postorbital bar. It makes a small contribution to the posterior base of the lateral

284 surface of the postorbital bar and medial face of the bar but does not have an extensive dorsal

285 process participating in the bar as in therocephalians (Durand, 1991; van den Heever, 1994).

286 The jugal is distinctly bowed in the zygoma, so that there is a ventral concavity below the 
287 postorbital bar. Posteriorly, the jugal makes up part of the subtemporal bar but is mostly overlain

288 by the zygomatic ramus of the squamosal.

289 The squamosal has a small contribution to the medial margin of the temporal fenestra

290 dorsally, but is mostly confined to the occiput and zygomatic arch (Fig. 4D). The sutures of the

291 occiput are largely indeterminable in this specimen, but given the proportions of the occiput it is

292 likely that the squamosals made up much of the lateral edge of the occiput as in other

293 gorgonopsians (Fig. 6A). The occipital and zygomatic portions of the squamosal are separated

294 by a sharp ridge with a flange-like ventral edge, anterior to which is a triangular depression, the

295 squamosal sulcus. Restriction of the sulcus to the zygomatic portion of the squamosal is an

296 unusual feature, usually this sulcus extends uninterrupted from the occiput around to the

297 zygoma or is entirely restricted to the occiput (as in rubidgein rubidgeines; Kammerer, 2016).

298 The only other taxon with this morphology is Viatkogorgon (Fig. 4B). The zygomatic ramus of

299 the squamosal terminates in a pointed anterior process dividing the jugal in lateral view; it does

300 not reach the level of the postorbital bar.

301 The frontal is a hexagonal bone of the interorbital region (Figs 4D, 6A). It has a broad

302 contribution to the orbit compared to many gorgonopsians (in most rubidgeines it is excluded

303 entirely; Kammerer, 2016). Posteriorly, it terminates in a narrow, sliver-like process extending

304 between the postfrontal and a complementary anterior process of the parietal (Fig. 6A).

305 The postfrontal is relatively large in Nochnitsa (Fig. 6A), which is typical for basal

306 therapsids but independently modified in most therapsid clades (lost in eutherocephalians,

307 cynodonts, and some anomodonts, and reduced in size in some later gorgonopsians [e.g.,

308 Arctognathus]; Hopson \& Barghusen, 1986; Kammerer, 2015). The postfrontal makes up the

309 posterodorsal corner of the orbit and extends posteriorly between the frontal and postorbital until

310 the level of the anterior border of the pineal foramen.

311 The postorbital is composed of a laminar dorsal ramus making up the medial border of

312 the temporal fenestra and a rod-like ventral ramus making up almost the entirety of the 
313 postorbital bar (Fig. 4D). A weak fossa serving as an attachment site for jaw musculature is

314 present on the ventrolateral edge of the dorsal ramus and continues onto the posterior edge of

315 the postorbital bar. The postorbital bar is weakly curved anteriorly and terminates in only a slight

316 anteroposterior expansion ventrally, unlike the massively expanded ventral postorbital tips of

317 most gorgonopsians (Sigogneau, 1970; Laurin, 1998; Kammerer et al., 2015; Kammerer, 2016).

318 The preparietal is a roughly rhomboidal median element situated between the frontals

319 and parietals (Fig. 6A). It is flush with the skull roof and unornamented. It is separated from the

320 pineal foramen by a short midline suture of the parietals; it does not abut the foramen directly as

321 in the majority of anomodonts and biarmosuchians (King, 1988; Sidor \& Rubidge, 2006).

322 The parietal is the primary skull roofing bone of the intertemporal region (Fig. 6A). It has

323 attenuate anterior and posterior processes; the latter mirrors the postorbital in following the

324 edge of the temporal fenestra. The anterior portion of the parietal midline is split by the small ( 3

$325 \mathrm{~mm}$ diameter), subcircular pineal foramen. It is surrounded by a distinct, collar-like rim but is not

326 elevated on a 'chimney'-like boss as in many basal therapsids.

327 As mentioned above, the bones of the occiput are not readily differentiable in this

328 specimen. There is a long, well-developed nuchal crest (Fig. 6A) that runs uninterrupted from

329 the top of the occipital plate to the foramen magnum along the midlines of what are probably the

330 postparietal and supraoccipital (based on the configuration seen in other gorgonopsians).

331 The dentary of Nochnitsa is very unusual for a gorgonopsian, much more closely

332 resembling that of a typical therocephalian. Notably, it lacks a steep, robust symphysis with a

333 distinct mentum, instead having a long, gradually sloping anterior face (Fig. 4D). The dentary

334 ramus posterior to the symphysis is relatively low and narrow, and the coronoid region is only

335 weakly sloped upward, with a convex posterior edge. In most gorgonopsians (including

336 Viatkogorgon; Fig. 4B) the dentary coronoid process is strongly dorsally directed with a distinctly

337 concave posterior face. The roots of four incisors (the standard number for gorgonopsians) can

338 be seen on the damaged right side of the dentary symphysis. They are similar in morphology to 
339 their upper counterparts, except apicobasally shorter (crown height $4 \mathrm{~mm}$ in i1, vs. $6 \mathrm{~mm}$ in I1).

340 The lower canines are mostly obscured by the upper jaw but their bases are visible-these

341 teeth are similar in size to the upper canine and situated anterior and medial to them. The lower

342 postcanines are very similar in individual morphology to the uppers but are not paired; instead,

343 they form a continuous row of close-packed, posteriorly-canted teeth (Fig. 5). Six lower

344 postcanines are exposed on each side, but in different parts of the tooth row (the posteriormost

345 left lower postcanines are exposed in the diastema between PC4 and 5, whereas the

346 posteriormost right lower postcanines are exposed in the diastema between PC2 and 3). This

347 suggests that the actual lower postcanine count exceeds six, especially considering that the

348 close spacing of these teeth necessitates more of them for the lower tooth row to approximate

349 the length of the upper.

350 The only exposed postdentary element is the reflected lamina of the angular, which is

351 best preserved on the left side (Fig. 4D). The entire reflected lamina is intact; it is angled

352 posteroventrally. This lamina is remarkably elongate and narrow (10 $\mathrm{mm}$ maximum length), and

353 tapers somewhat ventrally. A single robust ridge runs along the long axis of the reflected lamina.

354 This ridge is common to all gorgonopsians, but usually there is a second, horizontal ridge

355 making a cruciate pattern (Sigogneau-Russell, 1989), which is absent in Nochnitsa. Although

356 the articular is not exposed in this specimen, the proximity of the reflected lamina to the ventral

357 part of the squamosal that borders the quadrate necessitates that this taxon would have the

358 reflected lamina very close to the jaw articulation, which is the primitive condition for therapsids,

359 but unlike most gorgonopsians in which the reflected lamina is separated from the articular by a

360 length of non-laminar angular (Kammerer, 2016).

361 Part of the postcranium is preserved in articulation with the skull, including the cervicals,

362 some dorsals with associated ribs, and right forelimb (Figs. 1, 2). The cervical series is curled

363 around the left of the rear of the skull and still partially embedded in matrix (Fig. 1B). The axial

364 spine is broadly rounded and similar in morphology to that of other gorgonopsians (Sigogneau- 
365 Russell, 1989; Gebauer, 2014). The dorsals are preserved as fragments of centrum and

366 transverse processes interspersed with ribs. The ribs are simple, elongate elements. Above

367 these ribs on the left side of the specimen, the top of the right scapula is exposed. It is elongate,

368 narrow, and weakly curved, comparable to that of other small gorgonopsians (e.g.,

369 Cyonosaurus) but unlike the anteroposteriorly expanded scapular spines of Inostrancevia

370 (Sigogneau-Russell, 1989).

371 The right humerus, radius, ulna, and most of the manual elements are preserved in

372 partial articulation (Fig. 2B). The humerus is relatively gracile, with a short, weakly-developed

373 deltopectoral crest. The radius and ulna show distinct distal curvature, and the distal tip of the

374 radius forms a discrete edge differentiated from the shaft. No olecranon process is visible on the

375 ulna, but it is possible that this is the result of damage (the proximal tip of this element is not

376 complete and has partially been replaced by mudstone). Preserved proximal carpal elements

377 consist of the radiale, ulnare, and two irregular smaller elements that probably represent the

378 centralia. The ulnare is the proximodistally longest carpal and is expanded at its proximal and

379 distal tips. The radiale is a shorter, more rounded element. The possible centralia are poorly-

380 preserved but appear weakly curved. The concave surface of the centrale would presumably

381 have articulated with the radiale in life, based on the condition in other gorgonopsians

382 (Sigogneau-Russell, 1989). A clear intermedium is not visible; this element is usually small in

383 gorgonopsians and may either be missing or still buried in matrix. Several small, irregular bones

384 between the proximal carpals and metacarpals probably represent distal carpals, but these

385 elements are too poorly preserved to identify further. Based on their great length relative to the

386 other manual elements, the two best-preserved metacarpals probably represent 3 and 4 , which

387 are the longest metacarpals in all other gorgonopsians for which manus are known (Sigogneau-

388 Russell, 1989; Kümmell \& Frey, 2014). A shorter but still elongate element preserved

389 underneath the ulnare and a possible distal carpal may represent metacarpal 5. A semi-

390 articulated set of poorly-preserved bones appressed to the surface of the humerus and dentary 
391 appear to represent fingers, one potentially terminating in the ungual. Based on the size of the

392 phalanx-like elements, these probably correspond to the third and fourth digits, disarticulated

393 from metacarpal 3 and 4 . These elements are too poor for a definitive phalangeal count, and

394 there is no clear evidence of the disc-like reduced phalanges typically present in gorgonopsians

395 (Hopson, 1995).

396

397 Viatkogorgon Tatarinov, 1999a

398

399

Type species: Viatkogorgon ivakhnenkoi Tatarinov, 1999a.

400

Diagnosis: As for type and only species.

401

402

Viatkogorgon ivakhnenkoi Tatarinov, 1999a

403 (Figure 4)

404

405

Holotype: PIN 2212/61, a complete skeleton from the Kotelnich locality, Kotel'nichskii

406

District, Kirov Region, Russia.

407

Diagnosis: Distinguished from all other known gorgonopsians by the extremely large

408 squamosal sulcus, extending onto a squamosal flange impinging on the ventral edge of the temporal fenestra. Also characterized by unusually large orbit with proportionally large sclerotic ring. Distinguished from all gorgonopsians other than Nochnitsa by the narrow ventral terminus

411 of the postorbital bar. Further distinguished from Nochnitsa by the suite of features listed in the 412 Diagnosis for that taxon.

413 Description: The type specimen of Viatkogorgon ivakhnenkoi is one of the most

414 complete gorgonopsian specimens in the world, with nearly the entire postcranium preserved

415 intact, including elements very rarely preserved in therapsid specimens such as the gastralia.

416 Regrettably, the skull is poor by comparison-although the right side is reasonably well- 
417 preserved, the left side and palate are badly broken up and other than the snout tip and left

418 postorbital the skull roof is entirely reconstructed in plaster. Furthermore, the skull as a whole

419 has suffered from lateral compression, making it narrower in dorsal view than it would have

420 been in life. Detailed description of the postcranium of Viatkogorgon will greatly improve our

421 understanding of gorgonopsian skeletal anatomy; unfortunately it was not available for study

422 during the course of the current research (as it was part of a traveling exhibition) and must be

423 dealt with in a future contribution (a preliminary description was provided by Tatarinov [2004]).

424 The following description will focus on comparisons with Nochnitsa, necessarily centering on the

425 overlapping preserved portions of the skull (primarily the lateral surface and mandible).

426 Like that of Nochnitsa, the premaxilla of Viatkogorgon has limited exposure on the facial

427 surface of the snout (Fig. 4B). Although damaged even on the right side, its suture with the

428 maxilla is visible, and is in a similar position to that of Nochnitsa (below the base of the

429 septomaxillary footplate). The internarial bar is preserved, and is curved slightly posteriorly in

430 lateral view, so that the anterolateral margin of the snout in Viatkogorgon is blunt rather than

431 pointed. The dorsal tip of the premaxilla extends to the anterodorsal edge of the external naris.

432 Few upper incisors are preserved intact, but the typical gorgonopsian count of five appear to be

433 present based on the partial roots and alveoli. They are weakly recurved and spatulate with

434 clear distal serrations. It is uncertain whether they decrease in size posteriorly, as in Nochnitsa,

435 because the only incisors with intact crowns are both interpreted as the 15 of their respective 436 sides.

437 The septomaxilla of Viatkogorgon has a shorter posterior facial process than that of

438 Nochnitsa (Fig. 4B). Although the facial process separates the nasal and maxilla, as in most

439 therapsids (Hopson \& Barghusen, 1986), the absolute tip of the septomaxilla actually extends to 440 overlie the anterodorsal margin of the maxilla. Unlike that of Nochnitsa, the intranarial portion of

441 the septomaxilla is well preserved in Viatkogorgon. The septomaxilla is strongly constricted

442 between the small septomaxillary-maxillary foramen and the main narial opening. The 
443 septomaxillary footplate is dorsoventrally shallow and is underlain by a posterior process of the

444 premaxilla. The maxilla is proportionally taller and anteroposteriorly shorter than that of

445 Nochnitsa. Whereas the dorsal margin of the maxilla is broadly rounded in Nochnitsa (Fig. 4D),

446 in Viatkogorgon there is a broad posterodorsal process that extends between the nasal and

447 lacrimal. The posterior process of the maxilla is shorter in Viatkogorgon than Nochnitsa, not

448 reaching the midpoint of the orbit. The lateral surface of the maxilla is damaged on both sides of

449 the skull, but at least some radiating surface ridges were clearly present, as in Nochnitsa (Fig.

$4504 \mathrm{~A}, \mathrm{C})$. The precanine 'step' between the incisors and canine is notably steeper in Viatkogorgon

451 than Nochnitsa, and the canine-bearing portion of the maxilla in general is strongly convex,

452 giving the appearance of a flange in lateral view. The canine is relatively small for a

453 gorgonopsian, similar to Nochnitsa. It is serrated posteriorly. The postcanine tooth row is short,

454 consisting of only four close-packed postcanines. These postcanines are recurved, unlike those

455 of Nochnitsa. The maxilla is weakly emarginated above the postcanine tooth row, to a greater

456 extent than Nochnitsa but not to the degree in Eriphostoma (Kammerer et al., 2015) or

457 rubidgeines (Kammerer, 2016).

458 The nasal is somewhat broader anteriorly (at the level of the posterior edge of the

external naris) in Viatkogorgon than Nochnitsa, although this has been exaggerated in lateral

460

view by lateral compression in the skull (Fig. 4B). The prefrontal of Viatkogorgon is

461 proportionally shorter than that of Nochnitsa and contributes less to the anterodorsal margin of

462 the orbit (which instead has a greater contribution from the lacrimal). The prefrontal has

463 irregular, ragged edges with weak interdigitation with the maxilla anteriorly and lacrimal

464 ventrally. The posterior border of the maxilla is smoothly sloping in Nochnitsa, with progressively

465 shorter contributions to the snout from the prefrontal, lacrimal, and jugal (Fig. 4D). In

466 Viatkogorgon, the lacrimal has an anterior process breaking up the posterior border of the

467 maxilla posteriorly and extending to the same extent as the anterior tip of the prefrontal (Fig.

468 4B). As mentioned above, the lacrimal extends further dorsally along the rim of the orbit in 
469 Viatkogorgon than Nochnitsa. As in Nochnitsa, there is no exit on the lateral surface of the

470 lacrimal for the lacrimal foramen, which is restricted to the orbital wall.

471 A well-preserved, nearly undistorted sclerotic ring is preserved within the right orbit of

472 Viatkogorgon, consisting of 15 ossicles (Fig. 4B). This ring is remarkably large even within the

473 proportionally very large orbit (outer diameter $2.3 \mathrm{~cm}$, inner diameter $1.5 \mathrm{~cm}$, orbit diameter 2.8

$474 \mathrm{~cm}$ ), falling well within the range of what is considered scotopic in therapsids (Angielczyk \&

475 Schmitz, 2014) and suggesting nocturnal habits for Viatkogorgon. Fragments of the left sclerotic

476 ring are also preserved in the left orbit.

477 The jugal of Viatkogorgon has a more extensive facial contribution than that of Nochnitsa

478 (Fig. 4B). Its proportions in the zygoma, including the short contribution to the posterior base of

479 the postorbital bar, are very similar to those of Nochnitsa. However, it is substantially taller in the

480 subtemporal bar (which is taller in general than that of Nochnitsa) and more obscured by the

481 more anteriorly-extending squamosal (which extends almost to the level of the postorbital bar.)

482 In lateral view, the ventral portion of the jugal contribution to the subtemporal bar is barely

483 exposed, unlike the condition in Nochnitsa, where it is longer than the dorsal portion (Fig. 4D).

484 Little of the frontal is preserved in Viatkogorgon; only the portion contributing to the

485 orbital wall is intact (Fig. 4B). Within the orbit, the anterior border of the frontal is bifurcated by a

486 posterior process of the prefrontal. The postfrontal is represented solely by a thin strip of bone

487 at the posterodorsal edge of the orbit; it is otherwise reconstructed in plaster.

488 The dorsal ramus of the postorbital, like the rest of the intertemporal skull roof, is missing

489 in this specimen (Fig. 4B). The ventral ramus is a thin rod making up the postorbital bar (similar

490 to that of Nochnitsa, but somewhat anteroposteriorly broader). The postorbital bar is a straight

491 rod in lateral view, lacking the anteroventral curvature of Nochnitsa. It also has a weak posterior

492 fossa, presumably for attachment of the jaw muscles.

493 The zygomatic portion of the squamosal shows the same distinctly bounded squamosal

494 sulcus with posteroventral flange as in Nochnitsa, but is much larger and more expansive, and 
495 extends onto an anterodorsal flange at the ventral edge of the temporal fenestra (Fig. 4B). It is

496 also taller anterior to the sulcus and extends further forward on the subtemporal bar. Below the

497 squamosal sulcus the lateral edge of the quadrate is exposed, having disarticulated slightly from

498 the slot it fits into. The quadrate is preserved in articulation with the articular.

499 Unlike Nochnitsa, Viatkogorgon has the typical gorgonopsian jaw morphology, with a tall

500 mandibular symphysis bearing a distinct mentum (Fig. 4B). The lower dentition is poorly

501 preserved: a single intact incisor and postcanine are exposed on the left side, and the base of

502 the canine is visible on the right, anterior to the upper. The morphology of the lower teeth is very

503 similar to the uppers: the one preserved incisor is recurved and spatulate, the lower postcanine

504 is also weakly recurved, and both have at least posterior serrations. The dentary of

505 Viatkogorgon is generally taller in the ramus than that of Nochnitsa and has a more sharply

506 sloping coronoid process, with the weakly concave posterior edge typical of gorgonopsians.

507 Unfortunately the postdentary bones of Viatkogorgon are badly damaged, such that the

508 morphology of the reflected lamina is almost completely unknown. A narrow strip of this lamina

509 is preserved immediately posterior to the posteroventral edge of the dentary, but it shows no

510 morphology of note. What is evident is that the reflected lamina was situated well anterior to the

511 jaw articulation, like all gorgonopsians other than Nochnitsa. The surangular is exposed as a

512 narrow strip of bone at the top of the jaw posterior to the coronoid process of the dentary. It

513 extends to the articular posteroventrally but the contact between these bones is indistinct. The

514 articular is typical of gorgonopsians, with a ventrally-protruding retroarticular process. Damage

515 to this process makes it uncertain whether it had a hook-like anterior tip as in later

516 gorgonopsians (Kemp, 1969).

\section{PHYLOGENETIC ANALYSIS}

519 Nochnitsa geminidens and Viatkogorgon ivakhnenkoi were included in an expanded version of

520 the most recent published phylogenetic analysis of gorgonopsians, that of Kammerer (2017; 
521 itself an expansion of Kammerer [2016]). The original analysis of Kammerer (2016) was focused

522 on rubidgeine gorgonopsians in particular; in order to better understand the relationships of the

523 Kotelnich gorgonopsians, taxon sampling in the current analysis has been expanded to include

524 the Russian taxa Inostrancevia, Pravoslavlevia, Sauroctonus, and Suchogorgon. The early

525 therocephalian Lycosuchus vanderrieti was also included as a representative of the probable

526 sister-taxon of Gorgonopsia, Eutheriodontia (Therocephalia+Cynodontia) (Hopson \&

527 Barghusen, 1986).

528 In addition to expanding the taxon sample, the character matrix has been emended by

529 adding new characters and making alterations to several previous characters. These changes

530 are detailed below:

531 Character 2: Posterior margin of palatal premaxillary body. Previously (Kammerer, 2016), the

532 states for this character were formulated as (0) gently rounded and (1) with deep invaginations.

533 The biarmosuchian outgroups (Biarmosuchus and Hipposaurus) and the middle Permian

534 gorgonopsian Eriphostoma were the only taxa coded as (0) for this character; all other

535 gorgonopsians were coded as (1), or (?) if the anterior palate was not preserved or exposed.

536 This character was originally intended to encompass an important difference in palatal

537 morphology between gorgonopsians and non-gorgonopsian therapsids. In non-gorgonopsian

538 basal therapsids, such as biarmosuchians, the anterior margin of the choana is gently rounded,

539 with an even, gradual curvature between the body of the premaxilla and the vomerine process

540 of the premaxilla (Fig. 7A). In gorgonopsians, the anterior portion of the choana generally

541 extends further forwards in the form of a narrow channel, producing a distinct invagination

542 between the body of the premaxilla and the vomerine process (see, e.g., Kammerer, 2017:fig.

543 10). In rubidgeines, this invagination is particularly prominent (Fig. 7B), because the body of the

544 premaxilla is anteroposteriorly expanded relative to the condition in biarmosuchians and early

545 gorgonopsians like Eriphostoma. 
547 reconstruction of the palate in the holotype (Kammerer, 2014), although the premaxillary

548 morphology in that specimen is not exactly concordant with that of biarmosuchians. In the

549 Russian gorgonopsians in which this region is exposed (Inostrancevia, Sauroctonus, and

550 Suchogorgon), the premaxillary morphology is very similar to that of Eriphostoma. However, the

551 material of Suchogorgon is much better preserved than that of Eriphostoma and reveals that,

552 although it is not as distinctive as in rubidgeines, an invagination is present at the anterior edge

553 of the choana in that taxon (Ivakhnenko, 2005). One of the 'exploded' skulls of Suchogorgon

554 (PIN 4548/138) is particularly informative on this point, as the premaxillary-vomerine complex of

555 this specimen has been isolated and completely prepared (Fig. 7C). This specimen shows the

556 invagination to be morphologically distinct from (but probably representing the ancestral state

557 of) that of rubidgeines. Rather than being an elongate channel between expanded lobes of the

558 premaxillary body and vomerine process, the invagination in Suchogorgon is simply the result of

559 the vomerine process sloping dorsally, leaving a dorsoventral opening between its anterolateral

560 edge and the more ventrally-situated body of the premaxilla. In poorly preserved specimens,

561 such as the holotype of Eriphostoma microdon, this gap is difficult to see, but re-examination of

562 the CT-scan files for that specimen indicate that is was indeed present. Accordingly, character

563 state (1) has been changed from "with deep invaginations" to simply "invaginated", with

564 Eriphostoma now coded (1). The distinction between the morphology in

565 Eriphostoma/Suchogorgon and that of rubidgeines appears to be of phylogenetic importance

566 and is worthy of further study. At present it is difficult to encapsulate this distinction in character

567 form, however, because it seems to have undergone gradual transformation in gorgonopsian

568 evolution-in Gorgonops, for instance, the invagination is intermediate in morphology between

569 that of Suchogorgon and that of rubidgeines (see Kammerer, 2015:fig. 12C). 
571 Character 9: Vomerine-pterygoid contact. Previously (as character 7 of Kammerer [2016]), this

572 character had two states, (0) present and (1) absent. The absence of a contact between the

573 vomer and pterygoid is one of the classic gorgonopsian synapomorphies (Hopson \& Barghusen,

574 1986). However, as discussed in further detail below, Russian gorgonopsians with well-

575 prepared palates (Inostrancevia, Sauroctonus, and Suchogorgon) show that they still retained a

576 narrow but clearly present contact between the vomer and pterygoid (Fig. 8). The minimal

577 contact between these bones in these taxa still clearly distinguishes them from non-

578 gorgonopsian therapsids, so this character has been reformatted as ordered multistate: (0)

579 present, broad, (1) present, narrow, and (2) absent.

580

581 Character 10: Palatine foramina: (0) small or absent; (1) large, well-developed near maxillary

582 border. New character. In the Russian gorgonopsians Inostrancevia, Sauroctonus, and

583 Suchogorgon, there is a series of large, well-developed foramina on the palatine, near the

584 border with the maxilla (this region is not well-preserved in Pravoslavlevia). These foramina

585 appear to be absent in most African gorgonopsian taxa (this portion of the palatine is not

586 exposed in Nochnitsa or Viatkogorgon). The palatine surface is poorly-preserved (or more

587 usually, poorly-prepared) in many African gorgonopsian specimens, so this absence may be

588 partially artifactual. However, some African gorgonopsian specimens with excellently-prepared

589 palates (e.g., UMZC T891, Ruhuhucerberus haughtoni, and SAM-PK-K11458, Arctognathus

590 curvimola) clearly lack large palatine foramina. Comparable foramina are present and well-

591 developed in UMZC T878, however, the specimen of Sycosaurus nowaki that Kemp (1969)

592 described as Leontocephalus intactus.

593

594 Character 11: Dentition on palatine boss. Previously (as character 8 of Kammerer [2016]), this

595 character had three states, (0) extensive, (1) single long tooth row, and (2) few teeth in one

596 position. Eutheriodonts such as Lycosuchus lack palatine dentition, necessitating the addition of 
597 a fourth state, (3) absent. This character remains ordered, as absence of the palatine dentition

598 represents the endpoint of progressive reduction of these teeth.

599

600 Character 17: Parabasisphenoid blade position: (0) restricted to posterior edge of basicranial

601 girder; (1) extending throughout length of basicranial girder. New character. In most

602 gorgonopsians, the parabasisphenoid bears a tall, narrow, blade-like ventral crest. In

603 rubidgeines this 'blade' is absent, and the ventral surface of the parabasisphenoid exhibits a

604 reversal to the biarmosuchian condition, in which a narrow median channel separates the two

605 edges of the parabasisphenoid. The presence/absence of this feature is covered in character

60615 , but does not address an important difference in morphology between the Russian

607 gorgonopsians Inostrancevia, Sauroctonus, and Suchogorgon (the parabasisphenoid rostrum is

608 not well preserved in Pravos(avlevia) and non-rubidgeine African gorgonopsians. In the Russian

609 taxa, the 'blade' is nearly semi-circular in lateral view and restricted to the posterior portion of

610 the parabasisphenoid, near the back of the basicranial girder (as is also the case in

611 therocephalians), whereas in the African taxa the 'blade' is semi-oval and more elongate,

612 extending for almost the entire length of the basicranial girder (Fig. 9).

613

614 Character 28: Postorbital bar. Previously (as character 24 of Kammerer [2016]), this was

615 treated as an ordered multistate character with three states: (0) unexpanded, (1) expanded

616 (>10\% of basal skull length), and (2) greatly expanded ( $>20 \%$ of basal skull length). The primary

617 distinction in this formulation was between non-rubidgeine and rubidgeine gorgonopsians, with

618 the latter having anteroposteriorly expanded (and greatly expanded in the case of rubidgeins)

619 postorbital bars. However, this formulation did not address a difference between gorgonopsians

620 and outgroups like Biarmosuchia. In almost all known gorgonopsians, the ventral tip of the

621 postorbital bar is expanded where it contacts the jugal, even if it is narrow for the rest of its

622 length. The only known exceptions are Nochnitsa and Viatkogorgon, in which the postorbital bar 
623 is nearly the same width throughout its length (as in biarmosuchians). To reflect this, the states

624 for this character have been changed to (0) unexpanded (including biarmosuchians, Nochnitsa,

625 and Viatkogorgon), (1) expanded ventrally (non-rubidgeine gorgonopsians), (2) expanded

626 throughout length (>10\% of skull length) (non-rubidgein rubidgeines), and (3) greatly expanded

627 throughout length ( $>20 \%$ of skull length) (rubidgeins). The character is retained as ordered, as it

628 reflects increasing levels of expansion of this bone.

629

630 Character 29: Facial portion of jugal. Previously (as character 25 of Kammerer [2016]), this

631 character had two states: (0) confluent with suborbital zygomatic portion and (1) depressed

632 relative to zygomatic portion. State 1 was intended to describe the condition in some

633 rubidgeines, where there is a sharp break in surface height between the zygomatic and facial

634 portions of the jugal, with the latter depressed relative to the former. Pravoslavlevia and

635 Inostrancevia also exhibit a depressed facial portion of the jugal, but in a fundamentally different

636 way than in rubidgeines. In rubidgeines, the facial portion of the jugal is depressed relative to

637 the zygoma, but not adjacent facial bones (i.e., the jugal is not strongly depressed relative to the

638 maxilla and lacrimal, the surfaces of these bones are roughly confluent). In Pravoslavlevia and

639 Inostrancevia, there is a broad, deep preorbital fossa composed of the depressed facial

640 surfaces of the lacrimal and jugal. These bones are depressed relative to the adjacent prefrontal

641 and maxilla as well as the zygomatic portion of the jugal. Here, these different styles of facial

642 jugal depression are treated as separate, unordered character states, with the new states for

643 this character being (0) lateral surface confluent with other facial bones and suborbital

644 zygomatic portion of jugal, (1) depressed relative to zygomatic portion but not other facial

645 bones, and (2) bears broad fossa extending onto lacrimal surface, facial portion of jugal

646 depressed relative to both zygomatic portion and other (non-lacrimal) facial bones.

647 
648 Character 50: Lateral surface of reflected lamina. Previously (as character 45 of Kammerer

649 [2016]), this character had two states: (0) lobate sculpturing and (1) well-developed

650 dorsoventrally-oriented bar, with weakly-developed crossbar. The cruciate laminar sculpturing of

651 state (1) is characteristic of gorgonopsians. Uniquely among gorgonopsians, the reflected

652 lamina of Nochnitsa bears only the main, dorsoventrally-oriented bar; no crossbar is present. As

653 such this character has been changed to ordered multistate to reflect the intermediate condition

654 in Nochnitsa: (0) lobate sculpturing, (1) well-developed dorsoventrally-oriented bar only, and (2)

655 well-developed dorsoventrally-oriented bar, with weakly-developed crossbar.

656

657 This expanded version of the Kammerer (2016) data matrix (available as Supplemental

658 Information) is made up of 23 operational taxonomic units (OTUs; all species-level taxa except

659 for Inostrancevia, which was coded at the genus-level due to uncertain alpha taxonomy) and 52

660 characters. All characters are discrete-state, and of these, six are ordered multistate characters

661 (characters 11, 14, 26, 28, 31, 50). The phylogenetic analysis was run in PAUP* (Swofford,

662 2002) v4.0 (build 159) using branch-and-bound searching. Bootstrap analysis was done using

663 "fast" stepwise-addition on 1000 replicates.

664 The phylogenetic analysis recovered 6 most parsimonious trees (MPTs) of length 113

665 (Fig. 10), with a consistency index of 0.566, a retention index of 0.799 , and a rescaled

666 consistency index of 0.453 . Their topologies differ only in the relative positions of Arctognathus

667 curvimola, Lycaenops ornatus, and the clade made up of (Arctops willistoni+Smilesaurus ferox).

668 These taxa are always recovered just outside of Rubidgeinae but vary in precise position, with

669 Arctognathus recovered as the sister-taxon of Rubidgeinae in some MPTs and the

670 (Arctops+Smilesaurus) clade in others (Lycaenops is recovered either as sister to

671 (Arctops+Smilesaurus) or outside a clade containing those taxa and Rubidgeinae). Nochnitsa is

672 recovered as the earliest-diverging gorgonopsian taxon, followed by Viatkogorgon then a large

673 clade containing the remaining gorgonopsian OTUs. This clade is broken into two major 
674 subclades, one containing only Russian gorgonopsians (Suchogorgon, Sauroctonus,

675 Pravoslavlevia, and Inostrancevia) and the other containing all the African gorgonopsians

676 included in the analysis.

677

678 DISCUSSION

679 The position of Nochnitsa as the basalmost known gorgonopsian is supported by a number of 680 plesiomorphic characters, such as the low symphysis, low, sloping, therocephalian-like posterior 681 dentary, reflected lamina close to jaw articulation, no 'cross-bar' in reflected lamina surface, and 682 elongate tooth row (not restricted as in Viatkogorgon). Viatkogorgon is found outside of the 683 clade containing all remaining gorgonopsians, based on its lack of a ventral expansion on the 684 postorbital bar.

Remarkably, the remaining Russian gorgonopsian genera (Inostrancevia,

Pravoslavlevia, Sauroctonus, and Suchogorgon) were found to form a monophyletic group outside of the clade containing all African gorgonopsians. The monophyly of this group is currently weakly-supported, but their position outside of the 'African clade' is supported by several notable characters. The canonical synapomorphy of Gorgonopsia is a midline contact between the palatines, excluding the vomer from contact with the pterygoid; previous researchers considered this morphology to be present in all gorgonopsians (Hopson and

692 Barghusen, 1986; Sidor, 2000). However, our examination of the well-preserved holotype skull 693 of Sauroctonus progressus (PIN 156/6) revealed that, contra previous descriptions (Tatarinov, 694 1974; Sigogneau-Russell, 1989; Gebauer, 2014), there is actually a narrow vomerine-pterygoid 695 contact (Fig. 8A, C). Although this contact is substantially narrower than in any other therapsid 696 clade, it clearly prevents midline contact of the palatines. Further examination of the best-

697 preserved Russian gorgonopsian palatal material indicates that this contact is also retained in 698 Suchogorgon (Fig. 8B, D) and Inostrancevia (the palate is too poorly preserved in the only 699 known skull of Pravoslavlevia to determine). 

parabasisphenoid: this element bears a blade-like ridge extending the length of the basicranial girder, from the anterior edge of the basal tubera to the posterior edge of the transverse processes of the pterygoids (Fig. 9A, B). This blade is tallest in its posterior half but slopes gradually forwards, the only exception being in rubidgeines in which the blade has been secondarily lost. In Inostrancevia, Sauroctonus, and Suchogorgon, by contrast (this region is not well preserved in Pravoslavlevia), the parabasisphenoid blade is a tab-like structure restricted to the posterior part of the basicranial girder (Fig. 9C, D). This is more similar to the condition in therocephalians than to African gorgonopsians (van den Heever, 1994), and may represent the ancestral morphology within Theriodontia.

711 restricted major subclades of Gorgonopsia: a 'Russian clade' containing all Russian

712 gorgonopsians other than Nochnitsa and Viatkogorgon, and an 'African clade' containing the

713 South African and east African gorgonopsians in the data set (Fig. 10). Although there are

714 numerous African gorgonopsian taxa that have yet to be included in a phylogenetic analysis

715 (pending ongoing alpha taxonomic revision of the group), personal examination of those taxa by

716 the lead author indicates that they all have 'African clade'-style midline palatine contacts and

717 elongate parabasisphenoid blades, suggesting that they also belong to this clade. The recovery

718 of a monophyletic group containing the majority of Russian gorgonopsian taxa is novel to the

719 current study. Previous authors recognized no close relationship between Inostrancevia,

720 Sauroctonus, and Suchogorgon (although Inostrancevia and Pravoslavlevia have often been

721 grouped together, and were initially placed in the same genus). Tatarinov (1974) classified the

722 Russian gorgonopsians in different families, with Inostrancevia and Pravoslavlevia in

723 Inostranceviidae (containing only these two genera) and Sauroctonus in subfamily Cynariopinae

724 of family Gorgonopidae (also containing the African genera Aloposaurus, Aloposauroides,

725 Cynarioides, Cynariops, Scylacognathus, Scylacops, and Sycocephalus). Sigogneau-Russell 
726 (1989) classified Inostrancevia and Pravoslavlevia in subfamily Inostranceviinae of family

727 Gorgonopidae (one of only two gorgonopsian subfamilies she recognized, the other being

728 Rubidgeinae), leaving Sauroctonus as an undifferentiated gorgonopid. Ivakhnenko (2003)

729 classified Inostrancevia in a monogeneric Inostranceviidae, placing Pravoslavlevia,

730 Sauroctonus, and Suchogorgon in Gorgonopidae. Gebauer (2007) found Inostrancevia to be

731 deeply nested within African gorgonopsians, forming the sister-taxon of Rubidgeinae. She

732 recovered Sauroctonus as a basal gorgonopid, but also deeply-nested within a clade of

733 otherwise-African taxa (as she considered Aloposaurus, Cyonosaurus, and Aelurosaurus to be

734 basal, non-gorgonopid gorgonopsians).

735 At present, no described gorgonopsian specimens exhibiting the features of the 'African

736 clade' have been found in Russia, and vice versa. The purported Russian rubidgeine Leogorgon

737 klimovensis is not recognizable as a rubidgeine, and may not even be gorgonopsian

738 (Kammerer, 2016). Gebauer (2014) considered the Tanzanian gorgonopsian originally known

739 as Scymnognathus parringtoni (Huene, 1950) to be referable to the genus Sauroctonus.

740 However, personal examination of the type and only specimen of S. parringtoni (GPIT/RE/7113)

741 indicates that it has the typical parabasisphenoid and palatine morphologies of other African

742 gorgonopsians, and that cranial similarities between it and Sauroctonus (which consist primarily

743 of proportional characters that are variable among gorgonopsians) are superficial. Endemism in

744 gorgonopsians was previously unsuspected, and is surprising considering the many Russo-

745 African sister-taxon relationships in other therapsid groups, particularly dicynodonts and

746 burnetiamorphs (Sidor \& Smith, 2007; Kammerer et al., 2011). However, tetrapod biogeography

747 in the Permian remains poorly understood, and the inferred dispersal abilities of various

748 therapsid taxa are often discordant with the observed record (Sidor et al., 2013; Kammerer et

749 al., 2016). Additional research, particularly from regions outside of the well-sampled Karoo

750 Basin of South Africa, is required to understand the factors underlying tetrapod distribution

751 during this time. 
752

753 CONCLUSIONS

754 Two distinct gorgonopsian taxa are now known from the Russian Kotelnich locality:

755 Viatkogorgon ivakhnenkoi Tatarinov, 1999a and Nochnitsa geminidens gen. et sp. nov. Despite

756 this addition to the fauna's gorgonopsian diversity, gorgonopsians remain notably less species-

757 rich at Kotelnich than therocephalians (Ivakhnenko, 2011). Low diversity and small size of the

758 Kotelnich gorgonopsians suggests a predatory therapsid assemblage comparable to that of the

759 Pristerognathus AZ in the Karoo (Kammerer et al., 2015), prior to the main burst of

760 gorgonopsian diversification in South Africa. The phylogenetic position of Nochnitsa and

761 Viatkogorgon is also intriguing in this regard, as they are recovered as the most basal

762 gorgonopsians in our analysis. It is unlikely that this is actually indicative of an earlier age for the

763 Kotelnich locality than middle Permian gorgonopsian-bearing strata in South Africa (e.g., the

764 Abrahamskraal Formation, which yields specimens of Eriphostoma), based on the other

765 therapsid components of these faunas (notably the abundant eutherocephalians and absence of

766 dinocephalians at Kotelnich). However, even though the main 'Russian clade' of gorgonopsians

767 probably had diverged by the time of the Kotelnich fauna, its absence at the locality does

768 suggest it had not yet undergone substantial diversification in Russia, only later becoming the

769 dominant therapsid predators in the region.

770

771 ACKNOWLEDGEMENTS

772 We are very grateful to director A. Toporov, curator T. Berestova, and the staff members of the

773 Vyatka Paleontological Museum for permitting access to the holotype of Nochnitsa and for

774 supporting research at Kotelnich. For access to comparative materials we thank Valeriy

775 Golubev and the late Mikhail Ivakhnenko (PIN), Sifelani Jirah and Bernhard Zipfel (BP), Ingmar

776 Werneburg (GPIT), Paul Barrett (NHMUK), Robert and Marion Rubidge (RC), Zaituna Erasmus 
777 and Roger Smith (SAM), and Matt Lowe (UMZC). Finally, thanks to Adam Huttenlocker, Arjan

778 Mann, and Christian Sidor for reviewing the manuscript for this paper.

779

780 REFERENCES

781 Amalitzky V. 1922. Diagnoses of the new forms of vertebrates and plants from the Upper

782 Permian on North Dvina. Bulletin de l'Académie des Sciences de Russie (6)16:329-340.

783

784 Angielczyk KD, Schmitz L. 2014. Nocturnality in synapsids predates the origin of mammals by

785 over 100 million years. Proceedings of the Royal Society B 281:20141642. DOI

$78610.1098 /$ rspb.2014.1642.

787

788

Benton MJ, Walker AD. 1985. Palaeoecology, taphonomy, and dating of Permo-Triassic

789 reptiles from Elgin, north-east Scotland. Palaeontology 28:207-234.

790

791

Benton MJ, Newell AJ, Khlyupin AY, Shumov IS, Price GD, Kurkin AA. 2012. Preservation

792

of exceptional vertebrate assemblages in Middle Permian fluviolacustrine mudstones of

793

Kotel'nich, Russia: stratigraphy, sedimentology, and taphonomy. Palaeogeography,

794

Palaeoclimatology, Palaeoecology 319-320:58-83.

795

796

797

Bercovici A, Bourquin S, Broutin J, Steyer J-S, Battail B, Véran M, Vacant R,

Khenthavong B, Vongphamany S. 2012. Permian continental paleoenvironments in

798

Southeastern Asia: New insights from the Luang Prabang Basin (Laos). Journal of Asian Earth

799 Sciences 60:197-211.

800

801 Boos ADS, Kammerer CF, Schultz CL, Paes Neto VD. 2015. A tapinocephalid dinocephalian

802 (Synapsida, Therapsida) from the Rio do Rasto Formation (Paraná Basin, Brazil): Taxonomic, 
803 ontogenetic and biostratigraphic considerations. Journal of South American Earth Sciences

804 63:375-384.

805

806 Broom R. 1905. On the use of the term Anomodontia. Records of the Albany Museum 1:266-

807269.

808

809 Bystrov AP. 1955. [A gorgonopsian from the Upper Permian beds of the Volga]. Voprosy

810 Paleontologii 1955:7-18. [in Russian]

811

812 Coffa AA. 1997. Geology and stratigraphy of the Upper Permian Kotel'nich localily, Vyatka

813 River, Russia. Unpublished PhD Thesis, Monash University.

814

815 Coffa AA. 1997. Stratigraphy and correlation of the continental red bed sequence at the

816 Kotel'nich Upper Permian fossil tetrapod locality, Russia. Geological Society of Australia

817 Abstracts 46:15-17.

818

819 Coffa AA. 1998. Aeolian vs. fluvial origin for the Boroviki Member, Kotel'nich Upper Permian

820 fossil tetrapod localities, Vyatka Basin, Russia. Geological Society of Australia Abstracts 52:7.

821

822 Coffa AA. 1999. Sedimentology, stratigraphy and correlation of the continental red bed

823 sequence at the Kotel'nich Late Permian fossil tetrapod localities, Russia. In: Proceedings of

824 International Symposium "Upper Permian Stratotypes of the Volga Region". Geos: Moscow, 77-

82586.

826

827 Day MO, Ramezani J, Bowring SA, Sadler PM, Erwin DH, Abdala F, Rubidge BS. 2015.

828 When and how did the terrestrial mid-Permian mass extinction occur? Evidence from the 
829 tetrapod record of the Karoo Basin, South Africa. Proceedings of the Royal Society B

$830 \quad$ 282:20150834 DOI 10.1098/rspb.2015.0834.

831

832 Dias-da-Silva S. 2012. Middle-Late Permian tetrapods from the Rio do Rasto Formation,

833 Southern Brazil: a biostratigraphic reassessment. Lethaia 45:109-120.

834

835 Durand JF. 1991. A revised description of the skull of Moschorhinus (Therapsida,

836 Therocephalia). Annals of the South African Museum 99:381-413.

837

838 Efremov JA. 1940. [On the composition of the Severodvinian Permian Fauna from the

839 excavation of V. P. Amalitzky]. Comptes Rendus de l'Academie des Sciences de l'URSS

840 26:893-896. [in Russian]

841

842 Efremov JA, Vjushkov BP. 1955. [Catalogue of localities of the Permian and Triassic land 843 vertebrates on a territory of the USSR]. Trudy Paleontologicheskogo Instituta Akademii Nauk 844 SSSR 46:1-185. [in Russian]

845

846 Gebauer EVI. 2014. Re-assessment of the taxonomic position of the specimen GPIT/RE/7113

847 (Sauroctonus parringtoni comb. nov., Gorgonopsia). In: Kammerer CF, Angielczyk KD, Fröbisch

848 J, eds. Early Evolutionary History of the Synapsida. Dordrecht: Springer, 185-207, 337 pp. DOI

849 10.1007/978-94-007-6841-3_12.

850

851 Golubev VK. 2000. [Permian and Triassic chroniosuchians and biostratigraphy of the upper

852 Tatarian deposits of Eastern Europe by tetrapods]. Trudy Paleontologicheskogo Instituta 276:1853 176. [in Russian] 
855 Hartmann-Weinberg AP. 1937. Pareiasauriden als Leitfossilien. Problemy Paleontologii

856 2/3:649-712.

857

858 Hartmann-Weinberg A. 1938. Gorgonopsians as time indicators. Problems of Paleontology

859 4:47-123.

860

861 Hopson JA. 1995. Patterns of evolution in the manus and pes of non-mammalian therapsids.

862 Journal of Vertebrate Paleontology 15:615-639.

863

864 Hopson JA, Barghusen HB. 1986. An analysis of therapsid relationships. In: Hotton N III,

865 MacLean PD, Roth JJ, Roth EC, eds. The Ecology and Biology of the Mammal-Like Reptiles.

866 Washington, D.C.: Smithsonian Institution Press, 83-106, x +326 pp.

867

868 Huene F von. 1950. Die Theriodontier des ostafrikanischen Ruhuhu-Gebietes in der Tübinger

869 Sammlung. Neues Jahrbuch für Geologie und Paläontologie Abhandlungen 92:47-136

870

871 ICZN. 1999. International Code of Zoological Nomenclature. Fourth edition. London: The

872 International Trust for Zoological Nomenclature, $306 \mathrm{pp}$.

873

874 Ivakhnenko MF. 2003. Eotherapsids from the East European Placket (Late Permian).

875 Paleontological Journal 37:S339-S465.

876

877 Ivakhnenko MF. 2008. Cranial morphology and evolution of Permian Dinomorpha

878 (Eotherapsida) of Eastern Europe. Paleontological Journal 42:859-995.

879 
880 Ivakhnenko MF. 2011. Permian and Triassic therocephals (Eutherapsida) of Eastern Europe.

881 Paleontological Journal 49:981-1144.

882

883 Kammerer CF. 2014. A redescription of Eriphostoma microdon Broom, 1911 (Therapsida,

884 Gorgonopsia) from the Tapinocephalus Assemblage Zone of South Africa and a review of

885 Middle Permian gorgonopsians. In: Kammerer CF, Angielczyk KD, Fröbisch J, eds. Early

886 Evolutionary History of the Synapsida. Dordrecht: Springer, 171-184, 337 pp. DOI 10.1007/978-

887 94-007-6841-3_11.

888

889 Kammerer CF. 2015. Cranial osteology of Arctognathus curvimola, a short-snouted

890 gorgonopsian from the Late Permian of South Africa. Papers in Palaeontology 1:41-58. DOI

$891 \quad 10.1002 /$ spp2.1002.

892

893 Kammerer CF. 2016. Systematics of the Rubidgeinae (Therapsida: Gorgonopsia). PeerJ

894 4:e1608. DOI 10.7717/peerj.1608.

895

896 Kammerer CF. 2017. Anatomy and relationships of the South African gorgonopsian Arctops

897 (Therapsida, Theriodontia). Papers in Palaeontology 3:583-611. DOI 10.1002/spp2.1094. 898

899 Kammerer CF, Angielczyk KD, Fröbisch J. 2011. A comprehensive taxonomic revision

900 of Dicynodon (Therapsida, Anomodontia) and its implications for dicynodont phylogeny,

901 biogeography, and biostratigraphy. Society of Vertebrate Paleontology Memoir 11:1-158.

902

903 Kammerer CF, Bandyopadhyay S, Ray S. 2016. A new taxon of cistecephalid dicynodont from

904 the upper Permian Kundaram Formation of India. Papers in Palaeontology 2:569-584.

905 
906 Kammerer CF, Smith RMH, Day MO, Rubidge BS. 2015. New information on the morphology

907 and stratigraphic range of the mid-Permian gorgonopsian Eriphostoma microdon Broom, 1911.

908 Papers in Palaeontology 1:201-221. DOI 10.1002/spp2.1012.

909

910 Kemp TS. 1969. On the functional morphology of the gorgonopsid skull. Philosophical

911 Transactions of the Royal Society of London, Series B, Biological Sciences 256:1-83.

912

913 King GM. 1988. Anomodontia. Handbuch der Paläoherpetologie 17 C. Stuttgart: Gustav Fischer

914 Verlag, $174 \mathrm{pp}$.

915

916 Kümmell SB, Frey E. 2014. Range of movement in ray I of manus and pes and the prehensility

917 of the autopodia in the Early Permian to Late Cretaceous non-anomodont Synapsida. PLoS

918 ONE 9(12):e113911. DOI 10.1371/journal.pone.0113911.

919

920 Kurkin AA. 2011. Permian anomodonts: paleobiogeography and distribution of the group.

921 Paleontological Journal 45:432-444.

922

923 Laurin M. 1998. New data on the cranial anatomy of Lycaenops (Synapsida, Gorgonopsidae),

924 and reflections on the possible presence of streptostyly in gorgonopsians. Journal of Vertebrate

925 Paleontology 18:765-776. DOI 10.1080/02724634.1998.10011105.

926

927 Liu J, Xu L, Jia S-H, Pu H-Y, Liu X-L. 2014. The Jiyuan tetrapod fauna of the Upper Permian

928 of China-2. stratigraphy, taxonomical review, and correlation. Vertebrata PalAsiatica 52:328929339.

930 
931 Ochev VG, Surkov MG. 2000. The history of excavation of Permo-Triassic vertebrates from

932 Eastern Europe. In: Benton MJ, Shishkin MA, Unwin DM, Kurochkin EN (eds.) The Age of

933 Dinosaurs in Russia and Mongolia. Cambridge: Cambridge University Press, 1-16, 696 pp.

934

935 Olson EC. 1937. The cranial morphology of a new gorgonopsians. Journal of Geology 45:511936527.

937

938 Osborn HF. 1903. On the primary division of the Reptilia into two sub-classes, Synapsida and 939 Diapsida. Science 17:275-276.

940

941 Pravoslavlev PA. 1927. [Gorgonopsidae from the North Dvina expedition of V. P. Amalitzki].

942 Severo-Dvinskie raskopki Prof. V. P. Amalitskogo 3:1-117. [in Russian]

943

944 Ray S, Bandyopadhyay S. 2003. Late Permian vertebrate community of the Pranhita-Godavari 945 valley, India. Journal of Asian Earth Sciences 21:643-654.

946

947 Seeley HG. 1894. Researches on the Structure, Organisation, and Classification of the Fossil

948 Reptilia.-Part IX., Section 1. On the Therosuchia. Philosophical Transactions of the Royal

949 Society of London, Seires B, Biological Sciences 185:987-1018.

950

951 Sidor CA. 2000. Evolutionary trends and relationships within the Synapsida. Unpublished PhD

952 Thesis, University of Chicago.

953

954 Sidor CA, Rubidge BS. 2006. Herpetoskylax hopsoni, a new biarmosuchian (Therapsida:

955 Biarmosuchia) from the Beaufort Group of South Africa. In: Carrano MT, Gaudin TJ, Blob RW, 
956 Wible JR (eds.) Amniote Paleobiology: Perspectives on the Evolution of Mammals, Birds, and

957 Reptiles. Chicago: University of Chicago Press, 76-113, 547 pp.

958

959 Sidor CA, Smith RMH. 2007. A second burnetiamorph therapsid from the Permian Teekloof

960 Formation of South Africa and its associated fauna. Journal of Vertebrate Paleontology 27:420-

961430.

962

963 Sidor CA, Vilhena DA, Angielczyk KD, Huttenlocker AK, Nesbitt SJ, Peecook BR, Steyer

964 JS, Smith RMH, Tsuji LA. 2013. Provincialization of terrestrial faunas following the end-

965 Permian mass extinction. Proceedings of the National Academy of Sciences of the United

966 States of America 110:8129-8133.

967

968

Sigogneau D. 1970. Révision systématique des gorgonopsiens sud-africains. Cahiers de

Paléontologie. Paris: Centre National de la Recherche Scientifique, 417 pp.

970

971 Sigogneau-Russell D. 1989. Theriodontia I. Handbuch der Paläoherpetologie 17 B/I. Stuttgart:

972 Gustav Fischer Verlag, 127 pp.

973

974 Smith RMH, Rubidge BS, van der Walt M. 2012. Therapsid biodiversity patterns and

975 environments of the Karoo Basin, South Africa. In: Chinsamy A, ed. Forerunners of Mammals:

976 Radiation, Histology, Biology. Bloomington and Indianapolis: Indiana University Press, 223-246, $977330 \mathrm{pp}$.

978

979 Sues H-D, Munk W. 1996. A remarkable assemblage of terrestrial tetrapods from the Zechstein

980 (Upper Permian: Tatarian) near Korbach (northwestern Hesse). Paläontologische Zeitschrift

$981 \quad 70: 213-223$. 
982

983 Swofford DL. 2002. PAUP*. Phylogenetic analysis using parsimony ("and other methods).

984 Version 4. Sinauer Associates, Sunderland, Massachusetts.

985

986 Tatarinov LP. 1974. [Theriodonts of the USSR]. Trudy Paleontologicheskogo Instituta,

987 Akademiya Nauk SSSR 143:1-226. [in Russian]

988

989 Tatarinov LP. 1999a. New theriodonts (Reptilia) from the Late Permian fauna of the Kotelnich

990 Locality, Kirov Region. Paleontological Journal 33:550-556.

991

992 Tatarinov LP. 1999b. The first scaloposaurid (Reptilia, Theriodontia) from Russia (Upper

993 Permian, Kirov Region). Paleontological Journal 33:278-288.

994

995 Tatarinov LP. 2000a. A new gorgonopid (Reptilia, Theriodontia) from the Upper Permian of the

996 Vologda Region. Paleontological Journal 34:75-83.

997

998

Tatarinov LP. 2000b. New material of scaloposaurians (Reptilia, Theriodontia) from the Upper

999 Permian of the Kotelnich Locality, Kirov Region. Paleontological Journal 34:S187-S202.

1000

1001 Tatarinov LP. 2004. A postcranial skeleton of the gorgonopian Viatkogorgon ivachnenkoi

1002 (Reptilia, Theriodontia) from the Upper Permian Kotelnich locality, Kirov Region. Paleontological

1003 Journal 38: 437-447.

1004

1005 Tsuji LA. 2013. Anatomy, cranial ontogeny and phylogenetic relationships of the pareiasaur

1006 Deltavjatia rossicus from the Late Permian of central Russia. Earth and Environmental Science

1007 Transactions of the Royal Society of Edinburgh 104:81-122. 
1008

1009 Tverdokhlebov VP. 2009. [Facies-genetic analysis of Tatarian deposits and conditions of

1010 formation of the ‘Kotel'nich' locality]. Verkhniy Paleozoi Rossii: Stratigraficheskiya i Faunal'niyi

1011 Analiz, Kazan, 27-30 September 2009. Izdatel'stvo Kazan'skogo Universiteta 1-3. [in Russian]

1012

1013 van den Heever JA. 1994. The cranial anatomy of the early Therocephalia (Amniota:

1014 Therapsida). Universiteit van Stellenbosch Annale 1:1-59.

1015

1016 Vjuschkov BP. 1953. [On gorgonopsians from the Severodvinian Fauna]. Doklady Akademiya

1017 Nauk SSSR 91:397-400. [in Russian]

1018

1019 Wyllie A. 2003. A review of Robert Broom's therapsid holotypes: have they survived the test of 1020 time? Palaeontologia africana 39:1-19.

1021

1022 Young CC. 1979. [A Late Permian fauna from Jiyuan, Henan]. Vertebrata PalAsiatica 17:99_

1023 113. [in Chinese] 
1024 FIGURE CAPTIONS

1025

1026 Figure 1. Holotype block of Nochnitsa geminidens (KPM 310). (A) left lateral view with (B)

1027 interpretive drawing. Abbreviations: at, atlas; ax, axis; cr, cranium; cv, cervical vertebra; d,

1028 dentary; dv, dorsal vertebra; rla, reflected lamina of angular; r, rib; sc, scapula. Gray indicates

1029 matrix. Scale bar equals $1 \mathrm{~cm}$. Photograph and drawing by Christian F. Kammerer. [planned for

1030 page width]

1031

1032 Figure 2. Holotype block of Nochnitsa geminidens (KPM 310). (A) right lateral view with (B)

1033 interpretive drawing. Abbreviations: ce, centrale; d, dentary; dc, distal carpal; dpc, deltopectoral

1034 crest; h, humerus; mc, metacarpal; ph, phalanx; ra, radius; re, radiale; ul, ulna; ue, ulnare. Gray

1035 indicates matrix, hatching indicates plaster. Scale bar equals $1 \mathrm{~cm}$. Photograph and drawing by

1036 Christian F. Kammerer. [planned for page width]

1037

1038 Figure 3. Stereopair of KPM 310, holotype of Nochnitsa geminidens, in left lateral view.

1039 Scale bar equals $1 \mathrm{~cm}$. Photographs by Christian F. Kammerer. [planned for page width]

1040

1041 Figure 4. Kotelnich gorgonopsians compared in lateral view. (A) PIN 2212/6, holotype of

1042 Viatkogorgon ivakhnenkoi, in right lateral view with (B) interpretive drawing. (C) KPM 310,

1043 holotype of Nochnitsa geminidens, in left lateral view (mirrored for comparative purposes and

1044 with non-cranial parts of block edited out) with (D) interpretive drawing. Abbreviations: an,

1045 angular; ar, articular; C, upper canine; c, lower canine; d, dentary; fr, frontal; I, upper incisor; i,

1046 lower postcanine; j, jugal; la, lacrimal; mf, maxillary flange; mx, maxilla; na, nasal; pa, parietal;

1047 PC, upper postcanine; pc, lower postcanine; pf, pineal foramen; pmx, premaxilla; po, postorbital;

1048 pof, postfrontal; pp, preparietal; prf, prefrontal; rla, reflected lamina of angular; sa, surangular;

1049 sc, sclerotic ring; sf, squamosal flange; smx, septomaxilla; sq, squamosal; ss, squamosal 
1050 sulcus. Gray indicates matrix, hatching indicates plaster. Scale bars equal $1 \mathrm{~cm}$. Photographs

1051 and drawings by Christian F. Kammerer. [planned for page width]

1052

1053 Figure 5. Right marginal dentition of Nochnitsa geminidens. (A) close-up of holotype, KPM

1054 310, with (B) interpretive drawing. Abbreviations: C, upper canine; I, upper incisor; PC, upper

1055 postcanine; pc, lower postcanine; rC, replacement upper canine. Scale bar equals $1 \mathrm{~cm}$.

1056 Photograph and drawing by Christian F. Kammerer. [planned for page width]

1057

1058 Figure 6. Holotype skull of Nochnitsa geminidens (KPM 310) in dorsal view. (A)

1059 interpretive drawing and (B) photograph. Gray indicates matrix, hatching indicates plaster. Scale

1060 bar equals $1 \mathrm{~cm}$. Photograph and drawing by Christian F. Kammerer. [planned for page width]

1061

1062 Figure 7. Premaxillary-vomerine complex in biarmosuchians and gorgonopsians. (A)

1063 NHMUK R5700, holotype of the biarmosuchian Lycaenodon longiceps. (B) RC 35, holotype of

1064 the rubidgeine gorgonopsian Leontocephalus cadlei (considered synonymous with

1065 Aelurognathus tigriceps by Kammerer [2016]). (C) PIN 4548/138, a referred specimen of the

1066 Russian gorgonopsian Suchogorgon golubevi. All specimens in ventral view, anterior is right.

1067 Abbreviations: pi, premaxillary invagination; pmx, premaxilla; v, vomer. Scale bars equal $1 \mathrm{~cm}$.

1068 Photographs by Christian F. Kammerer. [planned for page width]

1069

1070 Figure 8. Photographs and interpretive drawings of the palates of Russian

1071 gorgonopsians. These illustrate the presence of a narrow contact between the vomer and

1072 pterygoid. (A), (C) PIN 156/5, holotype of Sauroctonus progressus. (B), (D) PIN 4548/1, referred

1073 specimen of Suchogorgon golubevi. Abbreviations: ec, ectopterygoid; mx, maxilla; PCa,

1074 postcanine alveolus; pl, palatine; ppl, palatal boss of palatine; ppt, palatal boss of pterygoid; pt, 
1075 pterygoid; tpt, transverse process of pterygoid; v, vomer. Scale bars equal $1 \mathrm{~cm}$. Photographs

1076 and drawings by Christian F. Kammerer. [planned for page width]

1077

1078 Figure 9. Photographs of the basicranial girder in Russian and African gorgonopsians.

1079 These illustrate the difference in morphology of the parabasisphenoid blade between these

1080 groups: elongate and sloping in African gorgonopsians (A, B), short and tab-like in Russian

1081 gorgonopsians (C, D). (A) BP/1/7275, referred specimen of Eriphostoma microdon. (B)

1082 BP/1/4089, referred specimen of Gorgonops torvus. (C) Cast of PIN 2005/1587, holotype of

1083 Inostrancevia alexandri. (D) PIN 156/6, holotype of Sauroctonus progressus. Parabasisphenoid

1084 blades highlighted in white to show outlines (dotted outline indicates broken surface). A-C in

1085 ventrolateral view, D in lateral view. Photographs by Christian F. Kammerer. [planned for page

1086 width]

1087

1088 Figure 10. Results of the phylogenetic analysis, showing the consensus of six most

1089 parsimonious trees. Values at nodes represent bootstrap support. Image by Christian F.

1090 Kammerer. [planned for page width] 
Figure 1

Holotype block of Nochnitsa geminidens (KPM 310).

(A) left lateral view with (B) interpretive drawing. Abbreviations: at, atlas; ax, axis; cr, cranium; cv, cervical vertebra; d, dentary; dv, dorsal vertebra; rla, reflected lamina of angular; r, rib; sc, scapula. Gray indicates matrix. Scale bar equals $1 \mathrm{~cm}$. Photograph and drawing by Christian F. Kammerer.

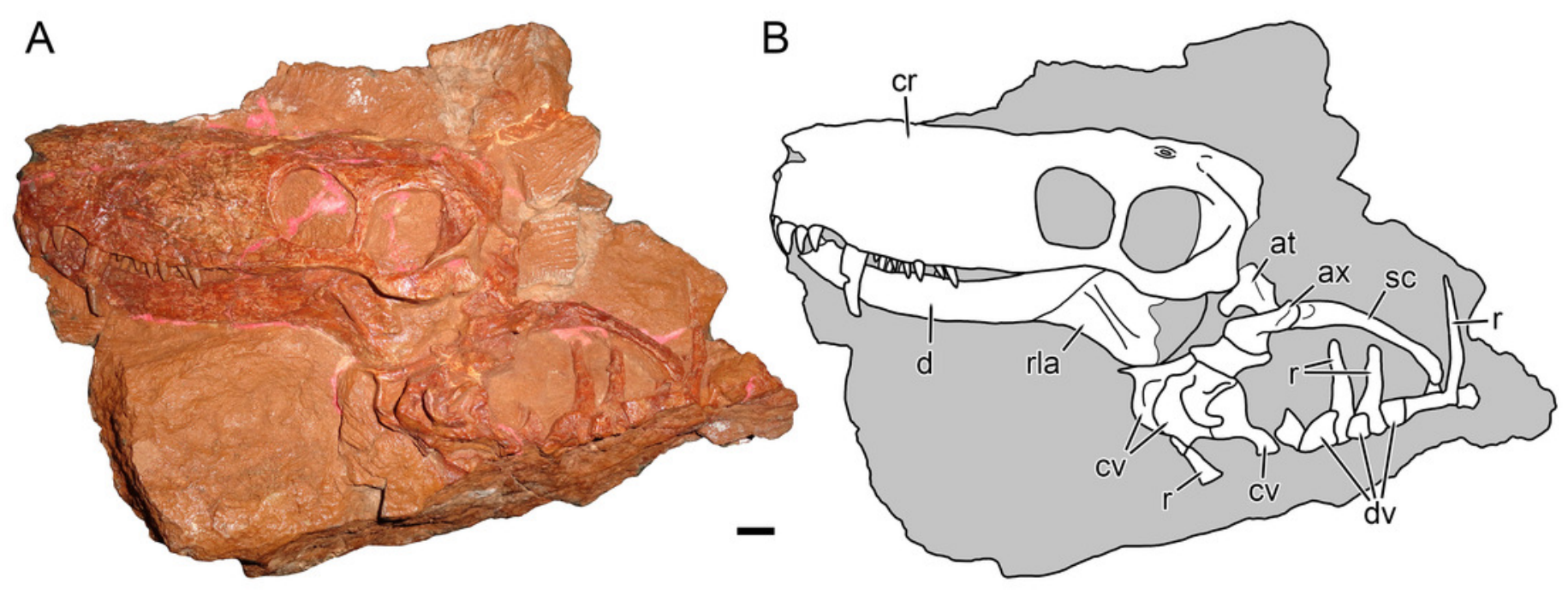




\section{Figure 2}

Holotype block of Nochnitsa geminidens (KPM 310).

(A) right lateral view with (B) interpretive drawing. Abbreviations: ce, centrale; d, dentary; dc, distal carpal; dpc, deltopectoral crest; $h$, humerus; mc, metacarpal; ph, phalanx; ra, radius; re, radiale; ul, ulna; ue, ulnare. Gray indicates matrix, hatching indicates plaster. Scale bar equals $1 \mathrm{~cm}$. Photograph and drawing by Christian F. Kammerer.

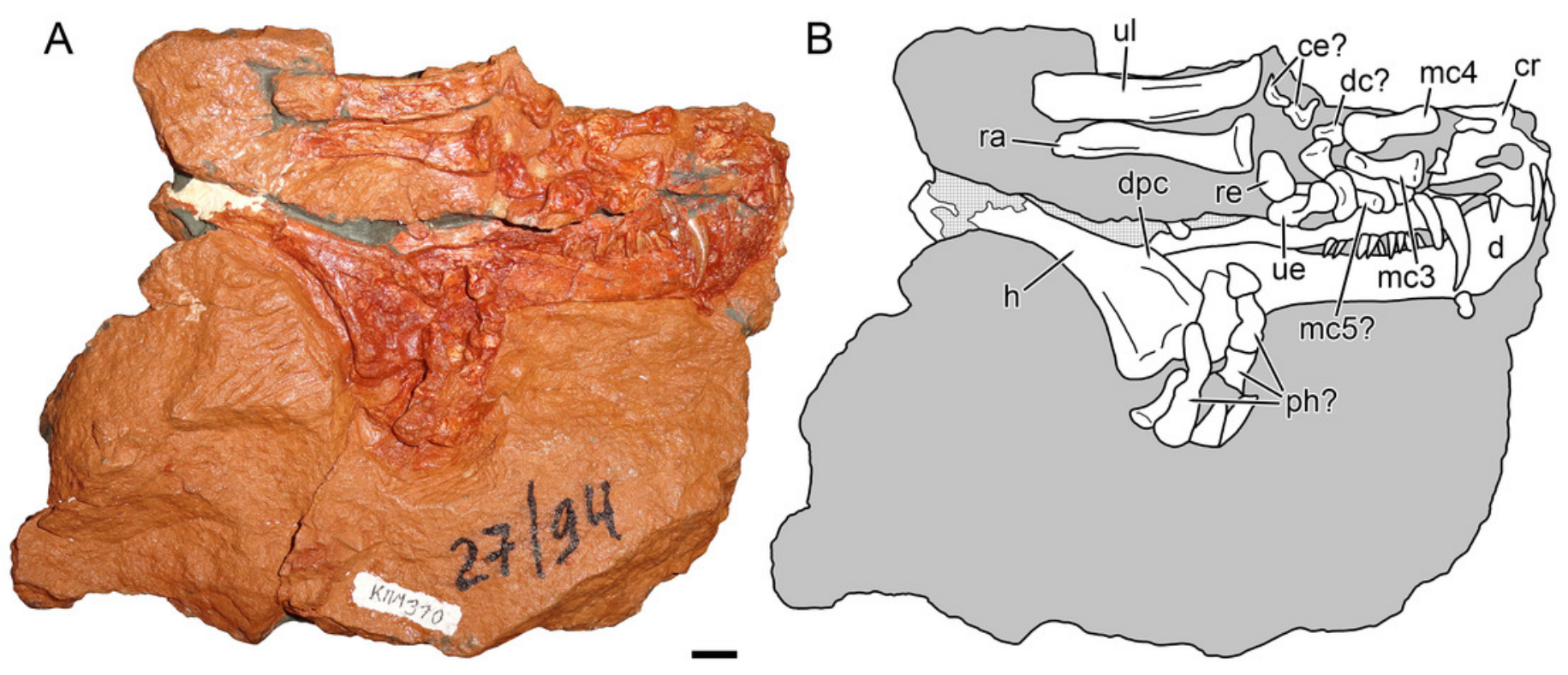


Figure 3

Stereopair of KPM 310, holotype of Nochnitsa geminidens, in left lateral view.

Scale bar equals $1 \mathrm{~cm}$. Photographs by Christian F. Kammerer.

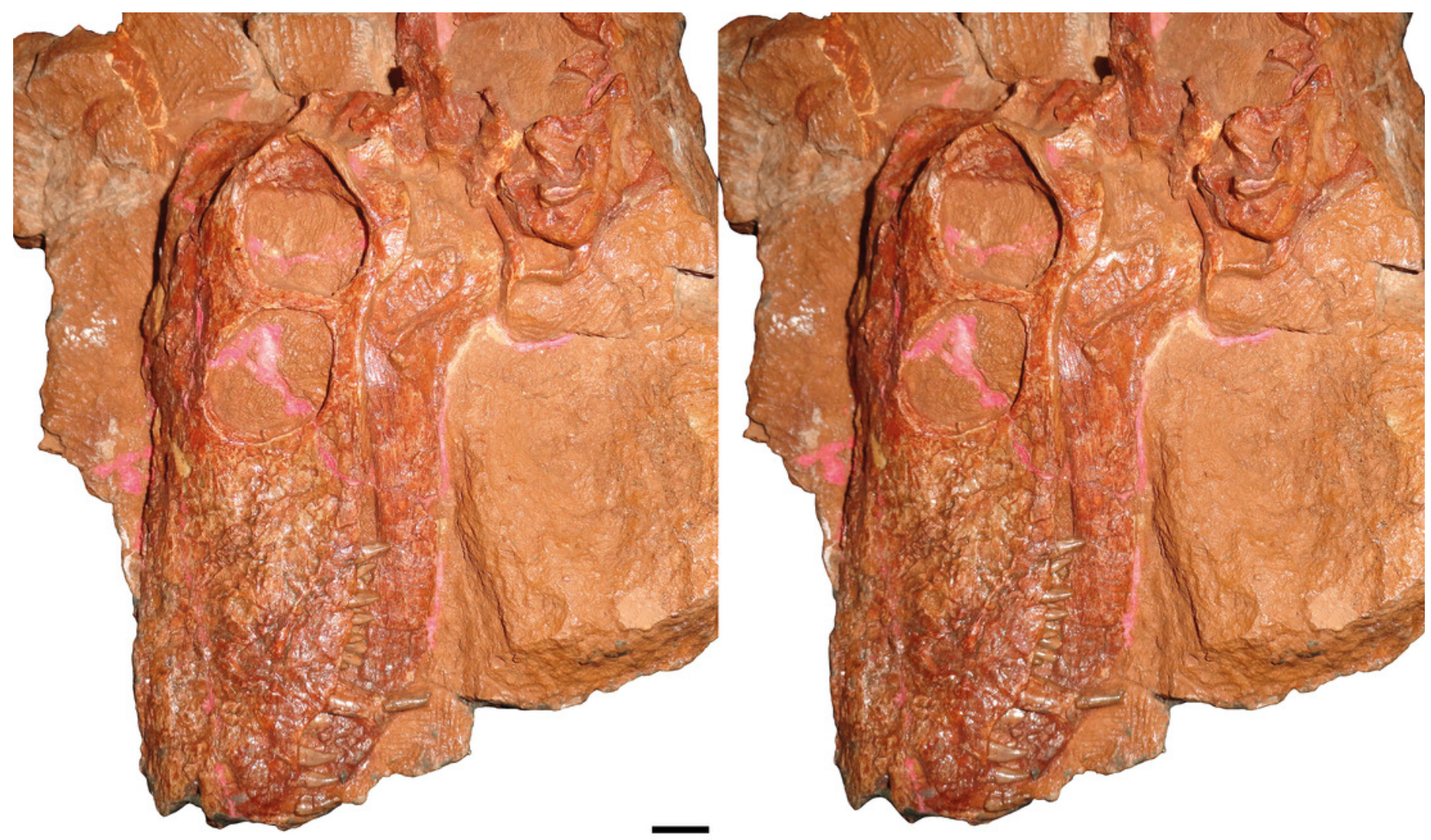




\section{Figure 4}

Kotelnich gorgonopsians compared in lateral view.

(A) PIN 2212/6, holotype of Viatkogorgon ivakhnenkoi, in right lateral view with (B) interpretive drawing. (C) KPM 310, holotype of Nochnitsa geminidens, in left lateral view (mirrored for comparative purposes and with non-cranial parts of block edited out) with (D) interpretive drawing. Abbreviations: an, angular; ar, articular; C, upper canine; c, lower canine; d, dentary; fr, frontal; I, upper incisor; i, lower postcanine; j, jugal; la, lacrimal; mf, maxillary flange; mx, maxilla; na, nasal; pa, parietal; PC, upper postcanine; pc, lower postcanine; pf, pineal foramen; pmx, premaxilla; po, postorbital; pof, postfrontal; pp, preparietal; prf, prefrontal; rla, reflected lamina of angular; sa, surangular; sc, sclerotic ring; sf, squamosal flange; smx, septomaxilla; sq, squamosal; ss, squamosal sulcus. Gray indicates matrix, hatching indicates plaster. Scale bars equal $1 \mathrm{~cm}$. Photographs and drawings by Christian F. Kammerer.
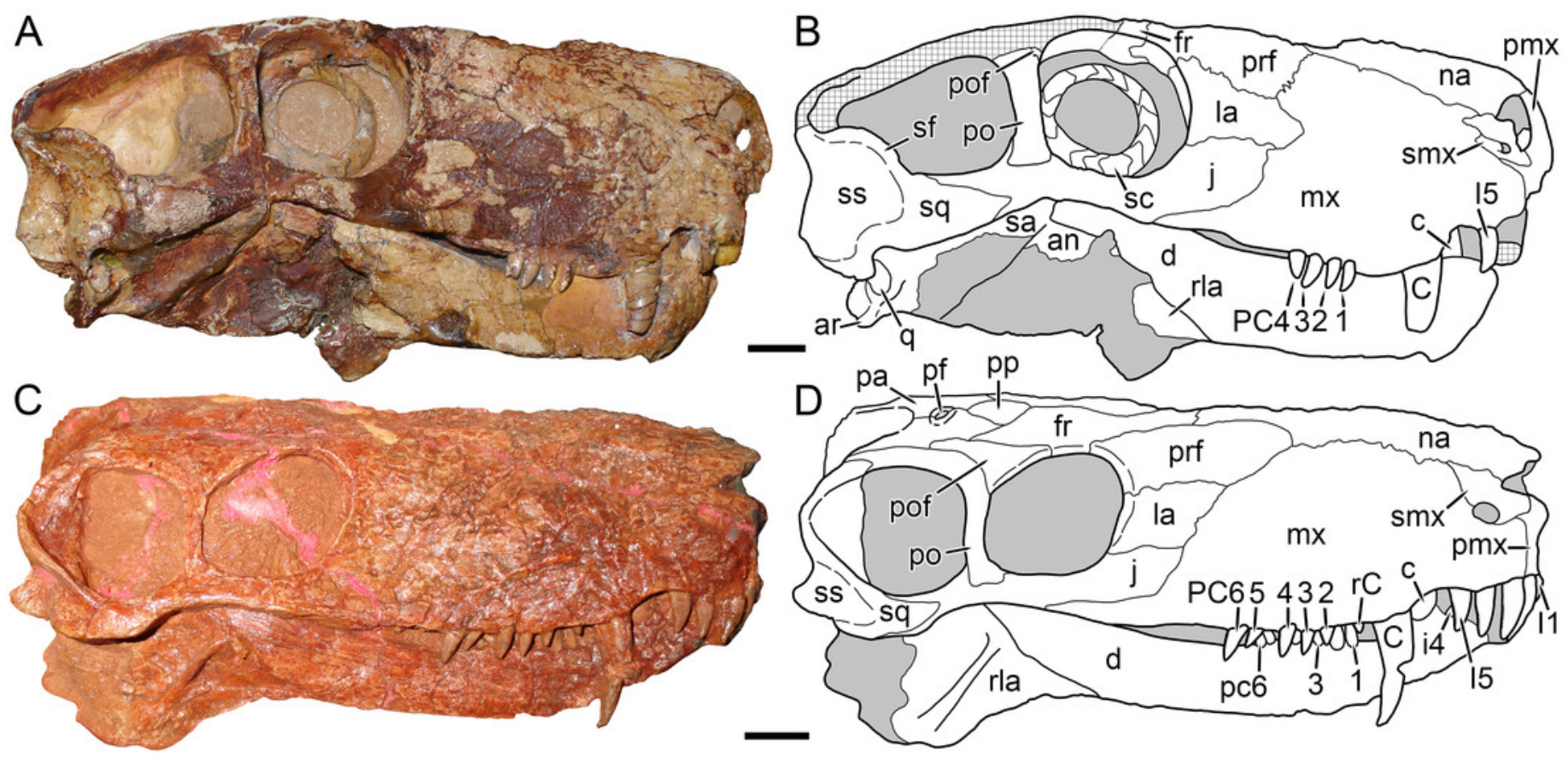


\section{Figure 5}

Right marginal dentition of Nochnitsa geminidens.

(A) close-up of holotype, KPM 310, with (B) interpretive drawing. Abbreviations: C, upper canine; I, upper incisor; PC, upper postcanine; pc, lower postcanine; rC, replacement upper canine. Scale bar equals $1 \mathrm{~cm}$. Photograph and drawing by Christian F. Kammerer. 

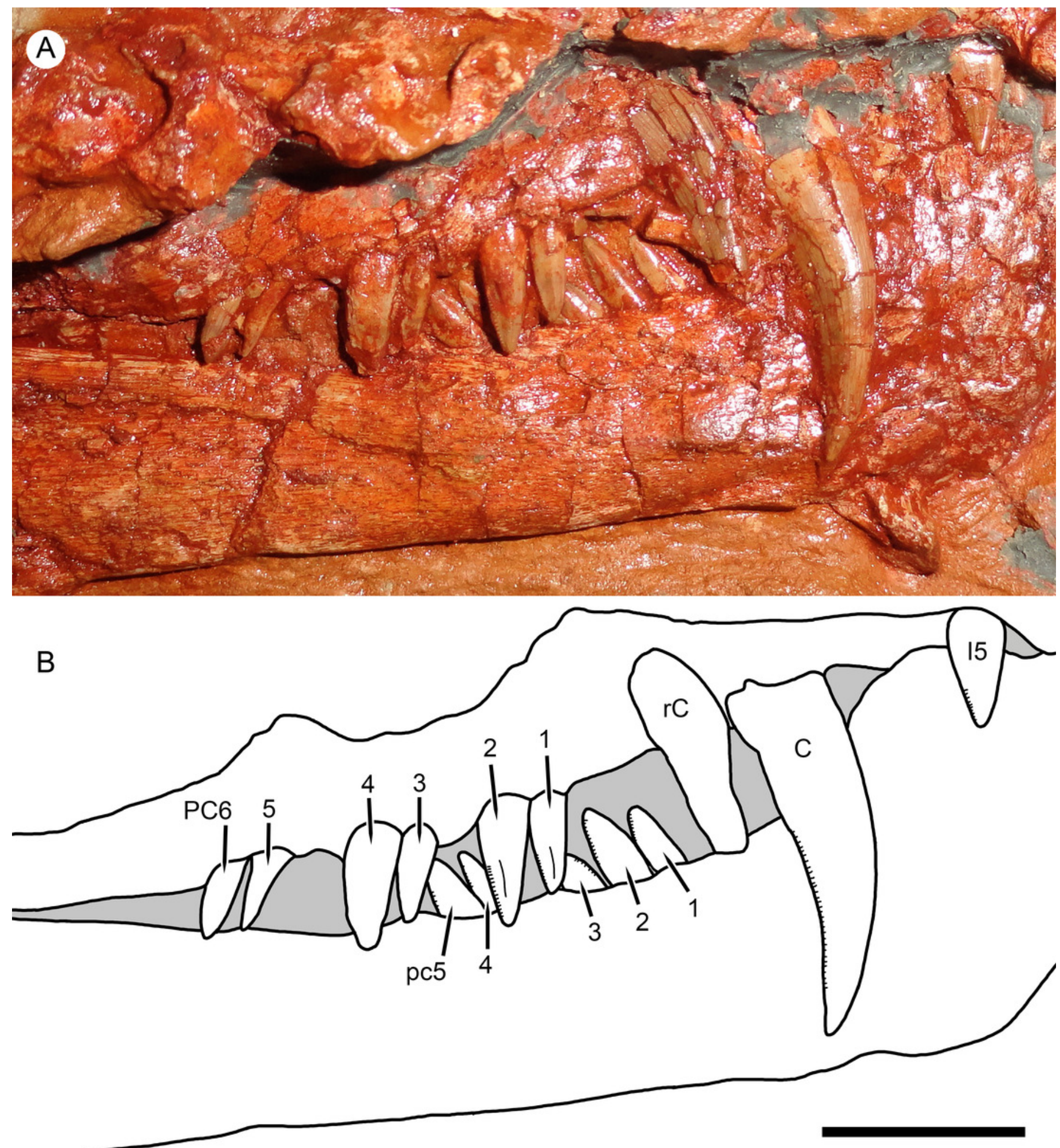
Figure 6

Holotype skull of Nochnitsa geminidens (KPM 310) in dorsal view.

(A) interpretive drawing and (B) photograph. Gray indicates matrix, hatching indicates plaster. Scale bar equals $1 \mathrm{~cm}$. Photograph and drawing by Christian F. Kammerer.
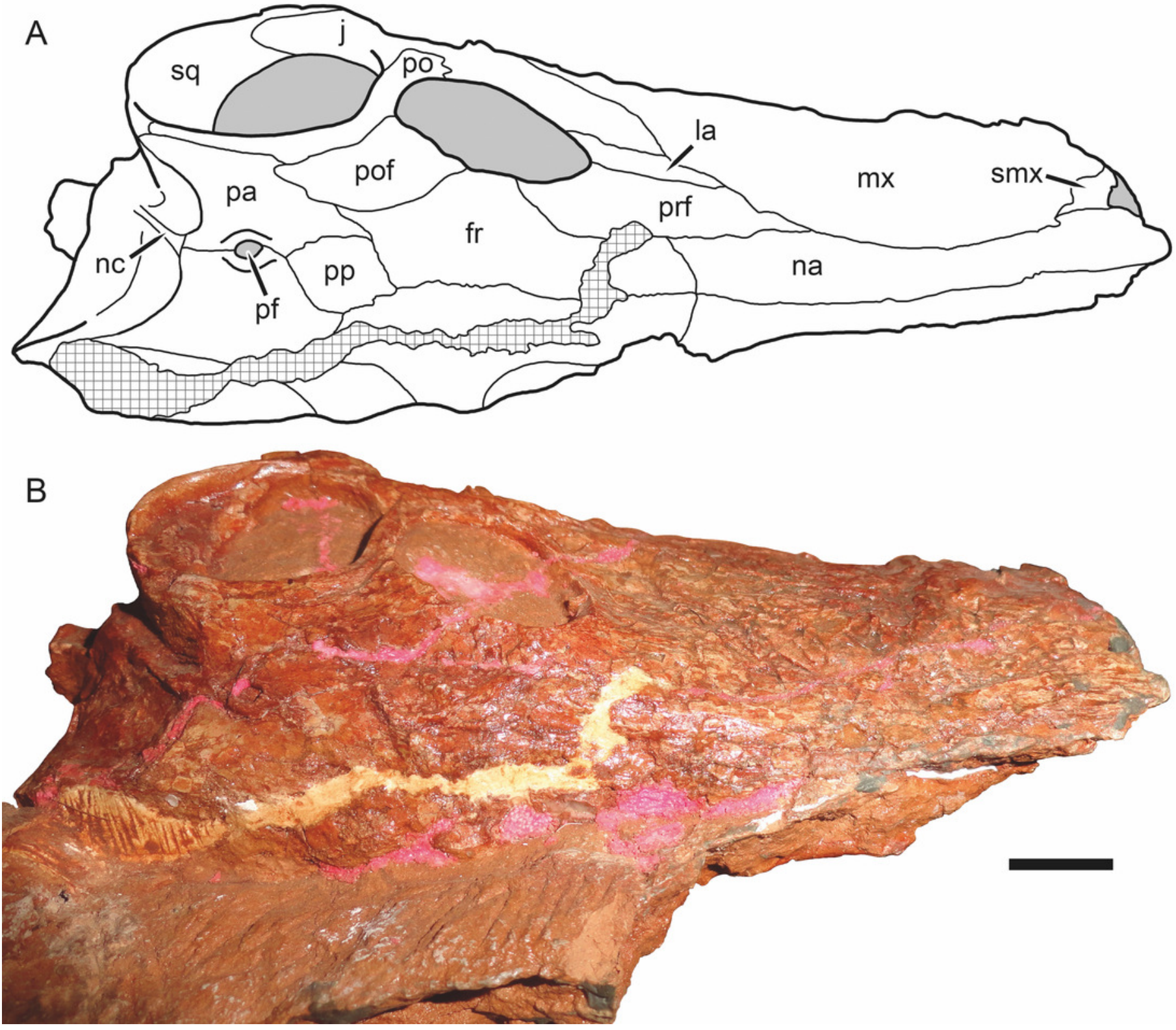


\section{Figure 7}

Premaxillary-vomerine complex in biarmosuchians and gorgonopsians.

(A) NHMUK R5700, holotype of the biarmosuchian Lycaenodon longiceps. (B) RC 35, holotype of the rubidgeine gorgonopsian Leontocephalus cadlei (considered synonymous with Aelurognathus tigriceps by Kammerer [2016]). (C) PIN 4548/138, a referred specimen of the Russian gorgonopsian Suchogorgon golubevi. All specimens in ventral view, anterior is right. Abbreviations: pi, premaxillary invagination; pmx, premaxilla; v, vomer. Scale bars equal 1 $\mathrm{cm}$. Photographs by Christian F. Kammerer.

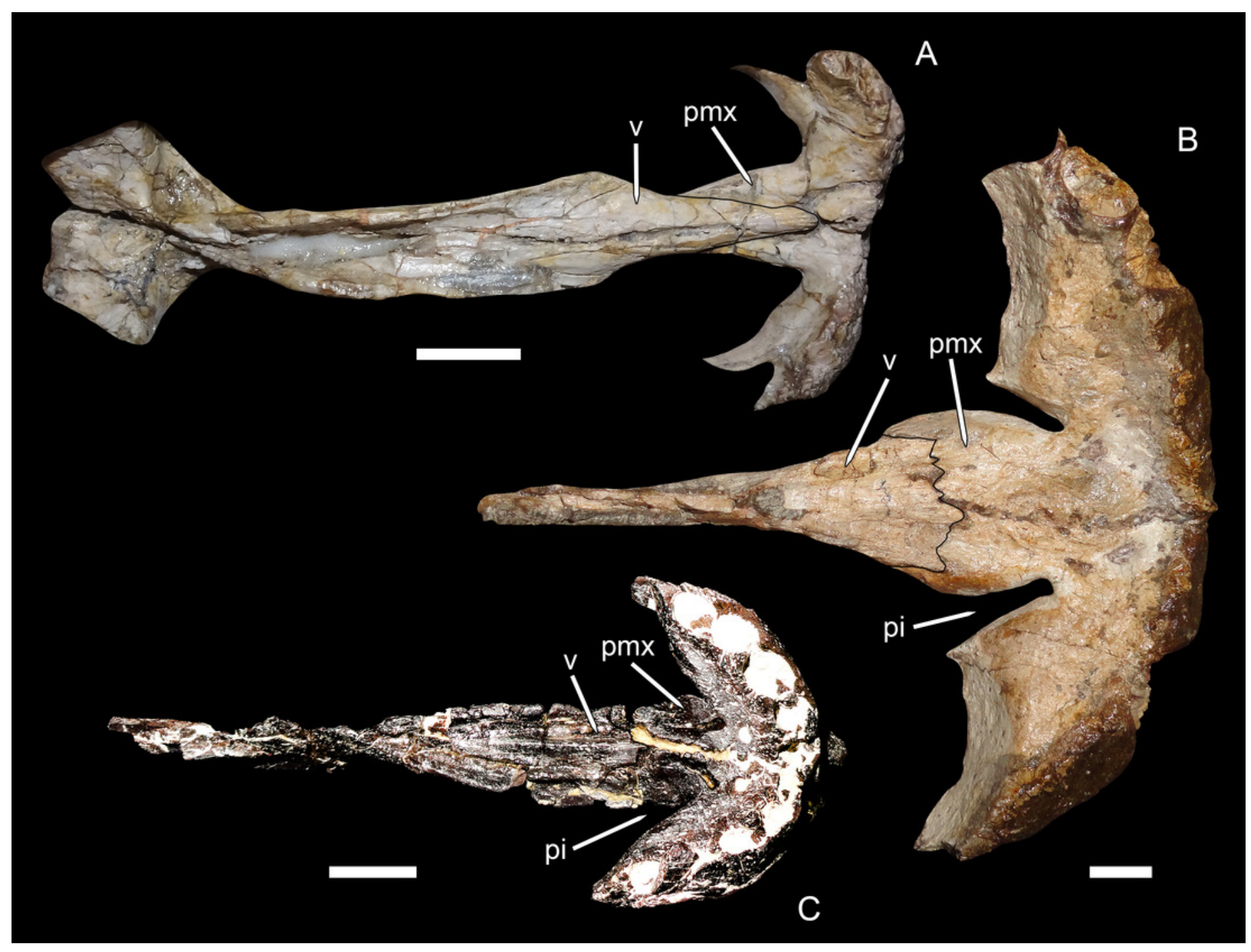




\section{Figure 8}

Photographs and interpretive drawings of the palates of Russian gorgonopsians.

These illustrate the presence of a narrow contact between the vomer and pterygoid. (A), (C)

PIN 156/5, holotype of Sauroctonus progressus. (B), (D) PIN 4548/1, referred specimen of

Suchogorgon golubevi. Abbreviations: ec, ectopterygoid; mx, maxilla; PCa, postcanine alveolus; pl, palatine; ppl, palatal boss of palatine; ppt, palatal boss of pterygoid; pt, pterygoid; tpt, transverse process of pterygoid; $v$, vomer. Scale bars equal $1 \mathrm{~cm}$. Photographs and drawings by Christian F. Kammerer. 


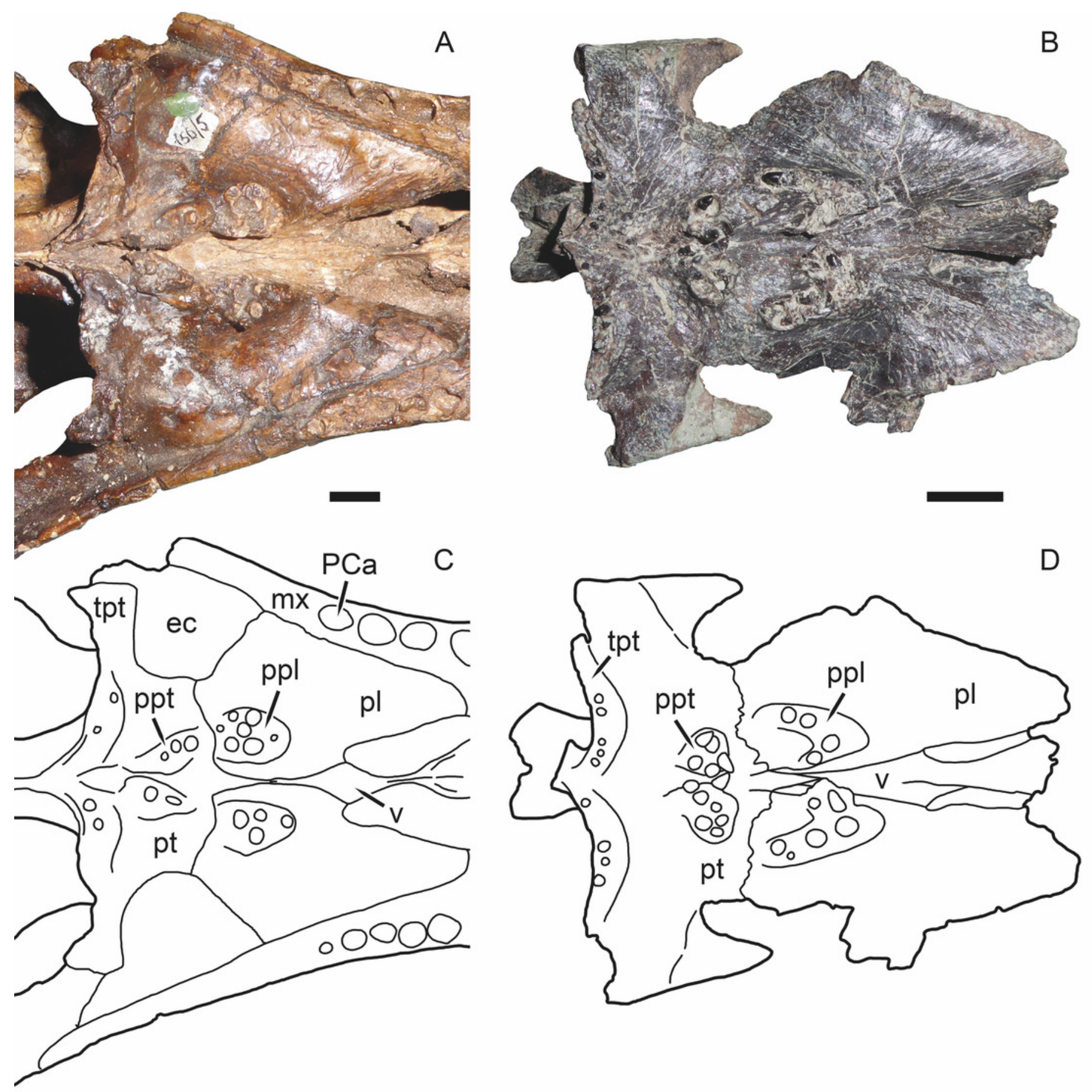




\section{Figure 9}

Photographs of the basicranial girder in Russian and African gorgonopsians.

These illustrate the difference in morphology of the parabasisphenoid blade between these groups: elongate and sloping in African gorgonopsians (A, B), short and tab-like in Russian gorgonopsians (C, D). (A) BP/1/7275, referred specimen of Eriphostoma microdon. (B) BP/1/4089, referred specimen of Gorgonops torvus. (C) Cast of PIN 2005/1587, holotype of Inostrancevia alexandri. (D) PIN 156/6, holotype of Sauroctonus progressus.

Parabasisphenoid blades highlighted in white to show outlines (dotted outline indicates broken surface). A-C in ventrolateral view, D in lateral view. Photographs by Christian F. Kammerer.

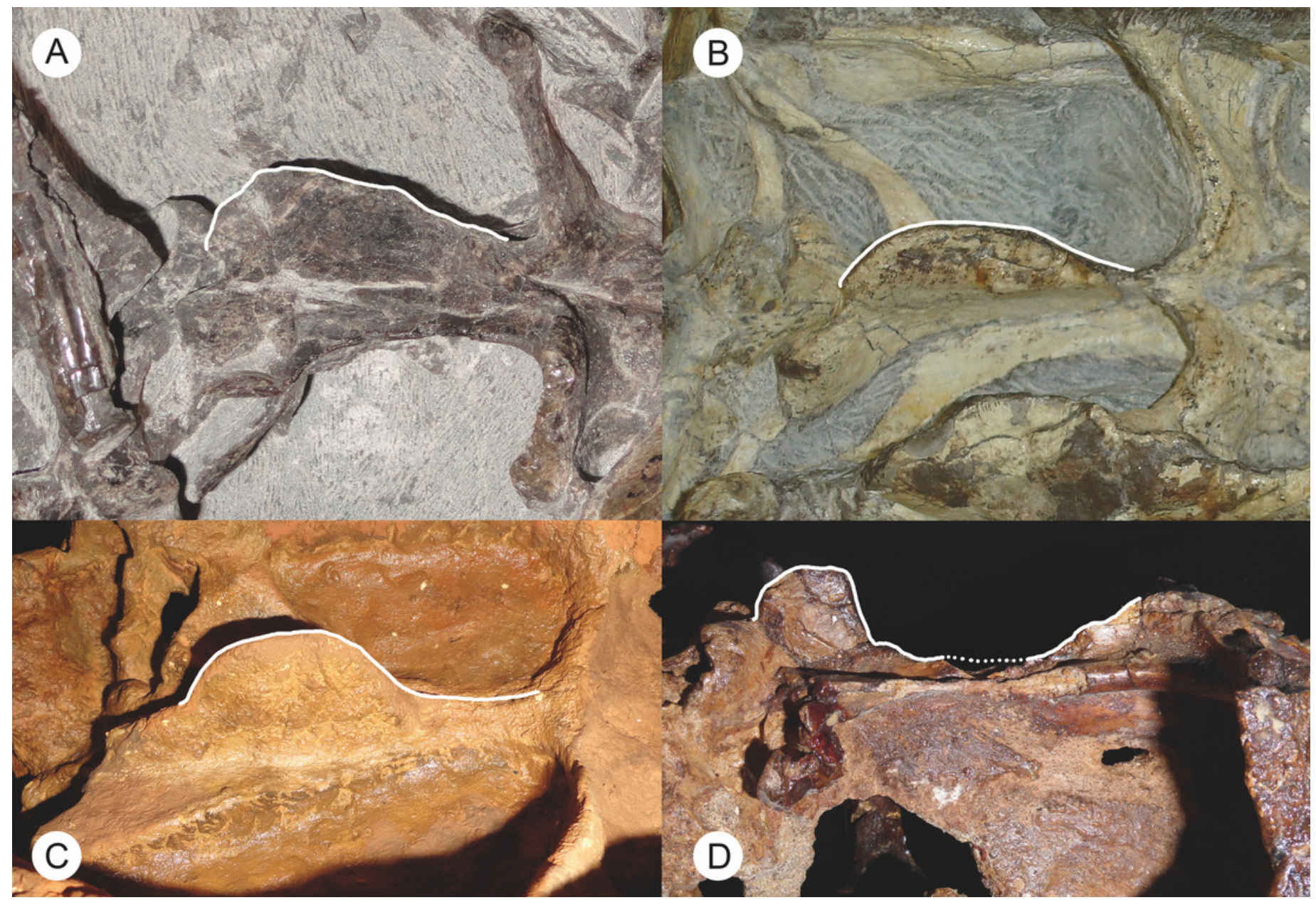


Figure 10

Results of the phylogenetic analysis, showing the consensus of six most parsimonious trees.

Values at nodes represent bootstrap support. Image by Christian F. Kammerer.

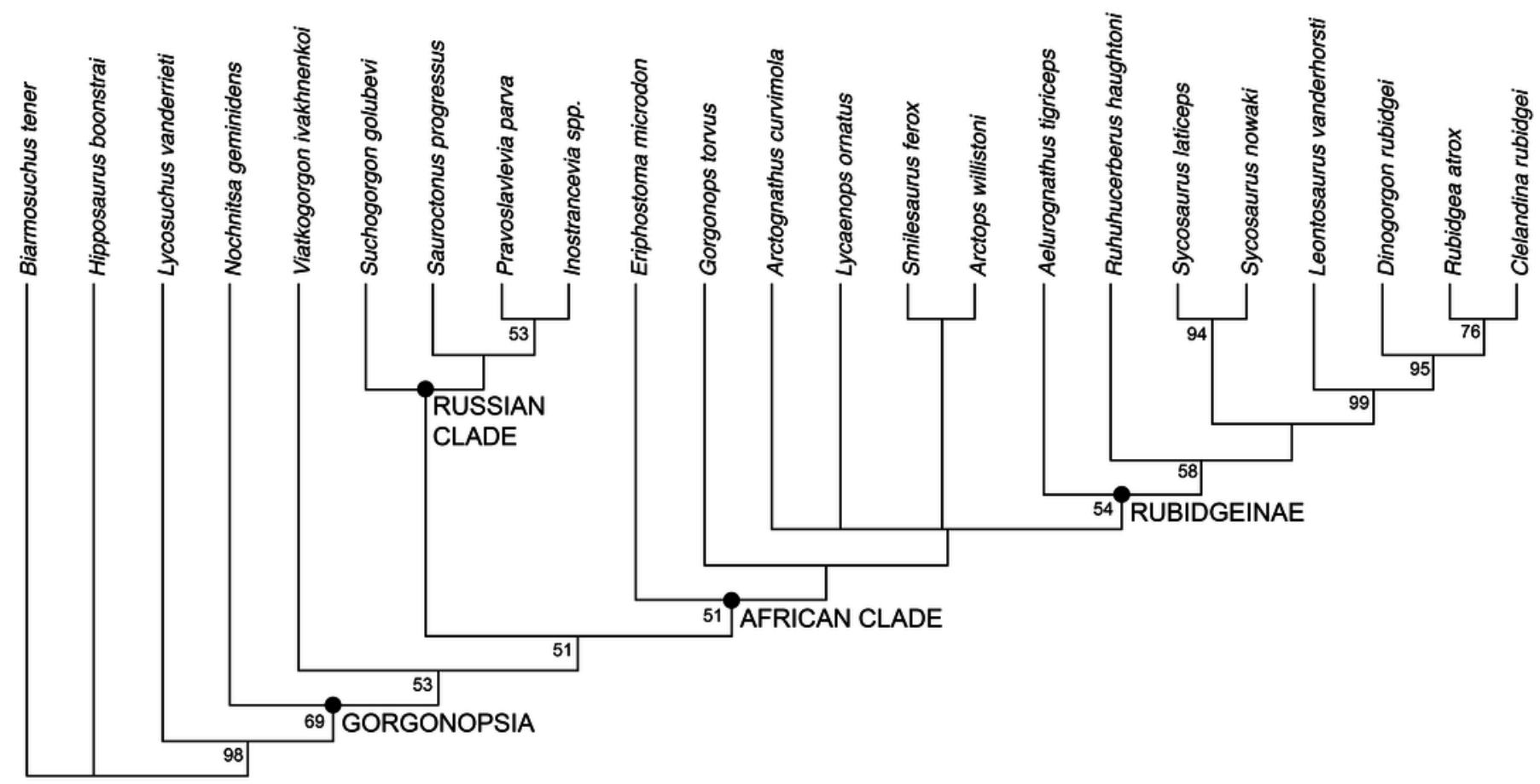

